\title{
Unified terminology for cestode microtriches: a proposal from the International Workshops on Cestode Systematics in 2002-2008
}

\author{
Lenta Chervy
}

University of Connecticut, Unit 3043, 75 N. Eagleville Rd., Storrs, Connecticut 06269-3043, USA

\begin{abstract}
Terminology for microtriches, the surface features both unique to and ubiquitous among cestodes, is standardised based on discussions that occurred at the International Workshops on Cestode Systematics in Storrs, Connecticut, USA in 2002, in České Budějovice, Czech Republic in 2005 and in Smolenice, Slovakia in 2008. The following terms were endorsed for the components of individual microtriches: The distal, electron-dense portion is the cap, the proximal more electron-lucent region is the base. These two elements are separated from one another by the baseplate. The base is composed of, among other elements, microfilaments. The cap is composed of cap tubules. The electron-lucent central portion of the base is referred to as the core. The core may be surrounded by an electron-dense tunic. The entire microthrix is bounded by a plasma membrane, the external layer of which is referred to as the glycocalyx. Two distinct sizes of microtriches are recognised: those $\leq 200 \mathrm{~nm}$ in basal width, termed filitriches, and those $>200 \mathrm{~nm}$ in basal width, termed spinitriches. Filitriches are considered to occur in three lengths: papilliform ( $\leq 2$ times as long as wide), acicular (2-6 times as long as wide), and capilliform ( $>6$ times as long as wide). In instances in which filitriches appear to be doubled at their base, the modifier duplicated is used. Spinitriches are much more variable in form. At present a total of 25 spinithrix shapes are recognised. These consist of 13 in which the width greatly exceeds the thickness (i.e., bifid, bifurcate, cordate, gladiate, hamulate, lanceolate, lineate, lingulate, palmate, pectinate, spathulate, trifid, and trifurcate), and 12 in which width and thickness are approximately equal (i.e., chelate, clavate, columnar, coniform, costate, cyrillionate, hastate, rostrate, scolopate, stellate, trullate, and uncinate). Spiniform microtriches can bear marginal (serrate) and/or dorsoventral (gongylate) elaborations; they can also bear apical features (aristate). The latter two modifiers should be used only if the features are present. The terminology to describe the overall form of a spinithrix should be used in the following order: tip, margins, shape. Each type of microthrix variation is defined and illustrated with one or more scanning electron micrographs. An indication of the taxa in which each of the microthrix forms is found is also provided.
\end{abstract}

Key words: microthrix, microtriches, Cestoda, ultrastructure, tegument

The monophyly of the cestodes is a concept that is now generally accepted, and has become relatively widely known. Less well known, however, is the fact that the monophyly of this class of platyhelminths is supported by a remarkably distinctive surface feature, unique to cestodes, often referred to as the microthrix. In addition to being unique to cestodes, microtriches appear to be ubiquitous among cestodes. They have now been reported from representatives of all cestode orders. They are present in the adult forms of all cestode species examined to date. They have also been reported from the earlier lifecycle stages of many cestode species. Not unexpectedly, with this taxonomic breadth has come a diversity of terminologies applied somewhat inconsistently among microthrix forms across different taxa and life-cycle stages. Discussions aimed at standardising microthrix terminology began at the 4th International Workshop on Cestode Systematics in Storrs, Connecticut in 2002, continued at the 5th International Workshop on Cestode Systematics and Phylogeny in České Budějovice, Czech Republic in 2005, and were concluded at the 6th International Workshop on Cestode Systematics in Smolenice, Slovakia, in 2008. This paper describes the terminology resulting from those discussions, adopted by the participating members of the global community of Cestodologists. This is the third in a series of papers aimed at standardising cestode terminology resulting from discussions at the International Cestode Workshops (see also Chervy 2002, Conn and Świderski 2008).

\section{Goals of this paper}

The primary goals of this paper were to develop a standardised terminology for (1) the components of individual microtriches, (2) the two basic types of microtriches, and, perhaps most importantly, (3) the diversity of forms of the two basic types of microtriches exhibited by cestodes.

In order to maximise the utility of the new terminology, its development was based on microthrix variation seen 
across as wide a taxonomic spectrum of cestodes as possible. To achieve this, an extensive survey was made of the literature. In addition, a number of specimens were examined de novo with scanning electron microscopy (SEM). We strove for a terminology that was descriptive, yet simple, but also flexible, in the hope that it could readily accommodate microthrix forms beyond those seen to date, because clearly much microthrix variation remains to be discovered. Our efforts were guided to some extent by similar efforts to standardise descriptors of morphological features in other taxonomic groups (e.g., Anonymous 1962, Clopton 2004). Brown (1956) and Borror (1960) served as rich sources of candidate terms to describe microthrix forms. It is our hope that this standardised microthrix terminology will serve to enhance the significance and predictive powers of comparative studies across cestode taxa, from both functional and phylogenetic standpoints.

\section{History}

Structures ornamenting the surfaces of cestodes were first observed in the 19th century. In the earliest reports, these features were described as "fibrilles protoplasmiques" (Sommer and Landois 1872), "Cilien" (Schiefferdecker 1874, Steudener 1877), "fibres" (Moniez 1881), or as "fine rods or threads" (Leuckart 1886). Descriptions of these structures early in the first half of the 20th century were somewhat more detailed (e.g., Goldschmidt 1900, Pratt 1909, Young 1908, Coutelen 1927, Rietschel 1935, Crusz 1947), with some studies including discussions of the development and/or the possible functions of these features. Hyman (1951; p. 320) described the outermost layer of the "cuticle" of cestodes as consisting of "a comidial layer...which is fringe-like and may be extended into fine hairs, spines, or scales". In the first study to present results from transmission electron microscopy (TEM) of the cestode tegument, Read (1955) reported "villus-like structures" on the surfaces of immature proglottids of both Raillietina cesticillus Molin, 1858 and $\mathrm{Hy}$ menolepis diminuta Rudolphi, 1819. He suggested these structures might maintain an intimate relationship with the mucosal surface and postulated that they might serve an absorptive function. Shortly thereafter, a number of additional authors observed these structures in a diversity of tapeworm taxa. For example, Kent (1957) reported and provided TEM images of "micropapilles" in several cyclophyllidean species, which he envisioned might engage between intestinal villosities. Rundell (1957) observed structures he referred to as "comidia" on the surfaces of five species of cyclophyllideans and one proteocephalidean. Rees (1958; p. 470) described "closely set, backwardly projecting structures which have been variously named 'pseudocilia', 'cirri', or 'hairs"' on the surface of the bothriocephalideans Bothriocephalus scorpii Müller, 1776 and Clestobothrium crassiceps (Rudolphi, 1819).
However, it was Rothman (1959) who, also employing TEM methods, argued convincingly for the unique nature of these cestode structures, proposing the terms microthrix (s.) and microtriches (pl.), and ultimately describing the various elements of these structures in some detail in 1963. Rothman (1963) was also the first to address the full spectrum of possible functions these structures might perform. Following quickly on the heels of Rothman's work, were investigations of these surface features in the adult and/or metacestode stages (sensu Chervy 2002) of a variety of other gyrocotylideans (Lyons 1969), caryophyllideans (e.g., Béguin 1966), diphyllobothriideans (e.g., McCaig and Hopkins 1965, Bråten 1968a, b, Charles and Orr 1968, Yamane 1968), trypanorhynchs and tetraphyllideans (e.g., Lumsden 1966), proteocephalideans (e.g., Threadgold 1964, 1965) and cyclophyllideans (e.g., Waitz 1961, Rosario 1962, Voge 1962, 1963, Siddiqui 1963, Howells 1965, Race et al. 1965, Lumsden 1966, Morseth 1966, 1967, Baron 1968, Lumsden et al. 1968), with many of these studies also employing TEM. Although Rothman's terms were not immediately universally adopted (e.g., for alternatives see Béguin 1966, Lee 1966, Morseth 1966), by the end of that same decade, they had essentially become the standards. Similarly, the ubiquity of microtriches among cestodes was generally accepted, as were their remarkable differences in form among taxa, life-cycle stages, and regions of the body. Much progress had also been made towards the characterisation of the microarchitecture of microtriches (e.g., Bråten 1968a, Lyons 1969, Morris and Finnegan 1969). For example, the universality of their bipartite nature, consisting of a distal electron-dense region and a proximal electronlucent region, despite the variety in form, had been firmly established. In 1969, Jha and Smyth provided a detailed account of microthrix structure and proposed formal terminology for some of the major components of individual microtriches.

Berger and Mettrick (1971) were the first to employ methods of SEM to explore the surface features of cestodes. Their work on the microtriches of the cyclophyllideans Hymenolepis diminuta (Rudolphi, 1819) and Hymenolepis nana (Rudolphi, 1819) provided a new perspective on microthrix form. They confirmed the existence of two distinct types of microtriches (i.e., a "short tubular form" and a "long flattened form"). Later that decade, papers describing two (or in some instances possibly more) types of microtriches appeared with some regularity as a result of work conducted using TEM and/ or SEM in caryophyllideans (e.g., Hayunga and Mackiewicz 1975), a spathebothriidean (Burt and Sandeman 1974), diphyllobothriideans (e.g., Kwa 1972, Grammeltvedt 1973, Lumsden et al. 1974, Andersen 1975, Yamane et al. 1975), trypanorhynchs (Lumsden 1975a, Halton and McKerr 1979), and also in bothriocephalideans (e.g., Timofeev and Kuperman 1972, Jones 1975, Boyce 
1976, Andersen 1979), tetraphyllideans (McVicar 1972, Gabrion and Euzet-Sicard 1979) and other cyclophyllideans (e.g., Jha and Smyth 1971, Featherston 1972, 1975, Blitz and Smyth 1973, Rees 1973, Euzet and Gabrion 1976, Hess and Guggenheim 1977, Hulínská 1977a, b, 1978, Gabrion and Euzet-Sicard 1979, Voge et al. 1979); an account of an unusual form in a lecanicephalidean also appeared early in the decade (e.g., Rifkin et al. 1970). Of note among works that decade was McVicar's (1972) detailed account of the close association between the microtriches of several tetraphyllideans and the microvilli of the spiral intestine of their host. Lumsden also provided comprehensive reviews of microthrix structure and, in particular, function (Lumsden 1975a, b).

In their seminal 1980 paper, Thompson et al. fully characterised the microtriches on the scolex of the proteocephalidean Kapsulotaenia tidswelli (Johnston, 1909). These authors adopted much of the terminology of Jha and Smyth (1969) for the specific components of microtriches. Based on extensive TEM work, they presented a detailed account of the structural and dimensional differences seen in microtriches among different regions of the scolex and strobila. They recognised several different varieties of filamentous microtriches (e.g., short or with a terminal membranous bleb) and also several different forms of robust microtriches (i.e., blade-like, spine-like, and peg-like) depending on the region of the scolex, neck, and strobila examined. They also provided insights into the different functions each of these forms might perform. They further demonstrated that some scolex structures that had previously been interpreted to be spines were, in fact, large microtriches.

The 1980's also saw the generation of SEM images of microtriches on the external surfaces of metacestodes and/or adults of additional species of bothriocephalideans (e.g., Pool and Chubb 1985), proteocephalideans (e.g., Coggins 1980, Jilek and Crites 1980) and cyclophyllideans (e.g., Valkounová and Prokopič 1980, Hulínská 1981, Czaplinski et al. 1988, Gijon-Botella et al. 1989), but also for the first time of amphilinideans (e.g., Rohde and Georgi 1983, Rohde 1986), haplobothriideans (e.g., Thomas 1983, MacKinnon et al. 1985), diphyllideans (e.g., Probert and Stobart 1989), and tetrabothriideans (e.g., Andersen and Lysfjord 1982). Some remarkable microthrix morphologies were observed in tetraphyllideans (Whittaker and Carvajal 1980, McCullough and Fairweather 1983, Whittaker et al. 1985, Caira and Pritchard 1986), and trypanorhynchs (Whittaker et al. 1982, 1985, McCullough and Fairweather 1983, Shields 1985, Andersen 1987, Carvajal et al. 1987, Hildreth and Lumsden 1987). However, TEM work continued, often also revealing unusual microthrix forms, on the various external surfaces of metacestodes and/or adults of caryophyllideans (Richards and Arme 1981a, b, Poddubnaya et al. 1986), haplobothriideans (MacKinnon and Burt 1985a, b, MacKinnon et al. 1985), diphyllobothriideans (Park et al. 1981, Yamane et al. 1982a, b, 1989, Ishii et al. 1988, Andersen and Gibson 1989), bothriocephalideans (e.g., Tedesco and Coggins 1980, Jarecka et al. 1981, Granath et al. 1983) and cyclophyllideans (Hulínská and Lavrov 1981, Mehlhorn et al. 1981, Schramlová and Lavrov 1981, Gabrion 1982, MacKinnon and Burt 1983, Novak and Dowsett 1983, Czaplinski et al. 1984, 1988, Holy and Oaks 1986, Conn 1988, Harris et al. 1989, Mizinska-Boevska et al. 1989).

The first studies aimed at determining the nature of the spine-like structures on the tegument lining elements of the reproductive system of cestodes began to appear that same decade. For example, using TEM, Beveridge and Smith (1985) convincingly demonstrated the presence of microtriches both in the vagina and on the cirrus of the tetraphyllidean Phyllobothrium vegans Haswell, 1902; they also noted having seen similar structures in a cyclophyllidean and a proteocephalidean. Similarly, Jones (1989) provided a detailed description of at least two different types of microtriches on the cirrus of the cyclophyllidean Cylindrotaenia hickmani (Jones, 1985).

In a classic TEM study, Holy and Oaks (1986) summarised the micro-architecture of microtriches in elegant detail and made several specific recommendations for the terminology applied to the individual components of these structures. For example, they noted that, based on their structure and composition, the cytoskeletal filaments in the base should be termed microfilaments, rather than microtubules, as they had been termed by some previous authors (e.g., Smyth 1969). Holy and Oaks (1986; fig. 20) also generated the most detailed and informative schematic illustration of a reconstruction of a microthrix available to date.

Kuperman (1980) provided a thoughtful analysis of the systematic significance of microtriches among cestodes. In one of the most comprehensive contributions to microthrix literature, based on extensive TEM and SEM work, Kuperman (1988) provided the first detailed treatment of microthrix form in a diphyllidean and spathebothriidean, and also for a diversity of bothriocephalidean, caryophyllidean, and trypanorhynch taxa. Furthermore, several reviews provided insights into the structure and function of microtriches in the model organism Hymenolepis diminuta (e.g., Lumsden and Specian 1980, Threadgold 1984), and in cestodes more generally (e.g., Lumsden and Murphy 1980, Halton 1982, Lumsden and Hildreth 1983, Smyth and McManus 1989).

Several extensive reviews treating the structure and/or possible functions of microtriches appeared early in the 1990's (e.g., Coil 1991, Hayunga 1991). However, the microthrix literature of that decade was dominated by papers employing SEM methods to characterise microtriches on the scolices of a wide array of taxa. In fact, the characterisation of scolex microtriches became a regular component of the descriptions of new cestode species. Taxa 
(novel or known) for which SEM data were generated included caryophyllideans (e.g., Poddubnaya 1995, 1996, Lyngdoh and Tandon 1996), diphyllobothriideans (Nishiyama et al. 1993, Tsuboi et al. 1993), trypanorhynchs (Richmond and Caira 1991, Palm 1995, 1997, Jones and Beveridge 1998, Palm et al. 1998, Campbell et al. 1999, Casado et al. 1999), diphyllideans (Ivanov and Campbell 1998a, Tyler and Caira 1999), tetraphyllideans (Caira 1990a,b 1992, Caira and Ruhnke 1990, 1991, Ruhnke 1993, 1994a, b, 1996a, b, Caira and Orringer 1995, Caira and Keeling 1996, Caira et al. 1996, Nasin et al. 1997, Ivanov and Campbell 1998b, McKenzie and Caira 1998), lecanicephalideans (e.g., Brockerhoff and Jones 1995), proteocephalideans (Hanzelová et al. 1995, Rego et al. 1999, Scholz et al. 1999), tetrabothriideans (e.g., Hoberg et al. 1995), and cyclophyllideans (e.g., Davydov et al. 1990, Irshadullah et al. 1990, Ashour et al. 1994, Casado et al. 1994, Cielecka et al. 1994, Bâ et al. 1995, Fourie et al. 1997). In an interesting TEM study, Biserova (1991), working with the diphyllidean Echinobothrium typus van Beneden, 1849, recognised two distinct types of microtriches. She used the term "polymicrothrix" for complex multidigitate forms of the larger microthrix type, and "microthrix" for all simple forms of microtriches. Within polymicrotriches, she distinguished between those of type 1 (with three digits) and type 2 (with greater than three digits).

Among other trends, these works confirmed that microthrix morphologies and/or distributions were consistent at a diversity of taxonomic levels (e.g., palmate microtriches restricted to some trypanorhynchs and diphyllideans; maiziform microtriches found only in a subset of tetraphyllidean genera including Paraorygmatobothrium Ruhnke, 1994, Orygmatobothrium Diesing, 1863, etc.). Based on extensive SEM of tetraphyllideans, Caira (1990b) advocated the systematic utility of scolex microtriches at least in onchobothriid tapeworms. As a result of SEM study of 27 taxa, Palm (1995) considered microthrix morphology to be of systematic utility in trypanorhynchs, particularly at the generic and specific levels. Recommendations for the standardisation of the regions of the scolex from which SEM images are routinely obtained were made for trypanorhynchs (e.g., Richmond and Caira 1991, Palm 1995) and tetraphyllideans (e.g., Caira 1990b, Caira et al. 1999, 2001). Caira et al. also provided a taxonomically comprehensive analysis of microthrix variation across cestode taxa, coding 23 SEM microthrix characters for 63 species in six cestode orders in 1999, and for 127 species in nine orders in 2001.

However TEM work also continued that decade with detailed information being provided on spathebothriideans (e.g., Davydov et al. 1997), diphyllobothriideans (e.g., Yazaki et al. 1990), bothriocephalideans (e.g., Davydov et al. 1995, Diaz-Castañeda et al. 1995, Žd'árská and Nebesářová 1997), proteocephalideans (e.g., Žd’árská and Nebesářová 1999), cyclophyllideans (e.g., Seif 1992,
Grytner-Zięcina et al. 1995), and amphilinideans (e.g., Davydov and Kuperman 1993).

The present decade has seen the generation of SEM data and/or in some instances also TEM data for microtriches in an even wider array of cestode taxa once again, especially in the context of the description of new species. Taxa examined have included additional gyrocotylideans (Poddubnaya et al. 2006), caryophyllideans (Poddubnaya 2003b, Poddubnaya et al. 2003), spathebothriideans (Marques et al. 2007, Poddubnaya 2007, Levron et al. 2008c), diphyllobothriideans (Chubb et al. 2006), diphyllideans (e.g., Faliex et al. 2000, Neifar et al. 2001, Tyler 2001, Ivanov and Lipshitz 2006, Twohig et al. 2008), trypanorhynchs (e.g., Beveridge and Jones 2000, Jones 2000, Palm 2000, Palm et al. 2000, Beveridge and Campbell 2001, Palm and Schröder 2001, Palm, 2008), bothriocephalideans (Poddubnaya, 2003a, Gil de Pertierra and Semenas 2005, 2006, Poddubnaya et al. 2007, Kuchta and Scholz 2008, Kuchta et al. 2008a, b, 2009, Levron et al. 2008a), cyclophyllideans (e.g., Stoitsova et al. 2001), lecanicephalideans (Ivanov and Campbell 2000, Jensen 2001, 2005, 2006), the first litobothriideans (Olson and Caira 2001), and the first cathetocephalideans (Caira et al. 2005).

However, figuring particularly prominently in this literature were the proteocephalideans (e.g., Bruňanská et al. 2000, Gil de Pertierra and de Chambrier 2000, Cañeda-Guzmán et al. 2001, de Chambrier 2001, 2003, 2004, 2006, de Chambrier et al. 2003, 2004, 2005, 2006a, b, 2007, 2008, 2009a, b, Gil de Pertierra 2002, 2004, 2005, 2009, Žd'árská and Nebesářová 2003, 2005, Žd'árská et al. 2004, Arredondo and Gil de Pertierra 2008, de Chambrier and Scholz 2008, Scholz et al. 2008) and the tetraphyllideans and rhinebothriideans (e.g., Caira and Burge 2001, Ghoshroy and Caira 2001, Caira and Zahner 2001, Caira and Tracy 2002, Ivanov and Brooks 2002, Ivanov and Campbell 2002, Healy 2003, 2006a, b, Caira et al. 2004, 2005, 2007a, b, Ivanov 2004, 2005, 2006, 2008, Agusti et al. 2005, Caira and Durkin 2006, Fyler and Caira 2006, Jensen and Caira 2006, 2008, Reyda and Caira 2006, Ruhnke and Thompson 2006, Ruhnke et al. 2006a, b, Reyda 2008, Ruhnke and Carpenter 2008, Twohig et al. 2008, Menoret and Ivanov 2009).

In addition, several monographs focusing on specific cestode orders provided SEM data for the microtriches of a substantial number of species and/or genera. In his monograph on the trypanorhynchs, Palm (2004) presented one or more SEM image of microtriches on the scolices of over 50 species representing a wide array of trypanorhynch families; he also provided TEM images to illuminate interpretation of some of the more interesting microthrix forms seen in certain members of this order. In their respective monographs, Jensen (2005) presented SEM images of exemplars of 11 lecanicephalidean genera, and Tyler (2006) provided SEM images of a total of 14 species in both genera of diphyllideans. In their revision of 
the bothriocephalideans, Kuchta et al. (2008b) presented SEM images of 27 species representing 27 genera.

Much headway was also made investigating the existence and nature of microtriches on the terminal genitalia of cestodes including bothriocephalideans (e.g., Poddubnaya 2003a, Levron et al. 2008b, Poddubnaya and Mackiewicz 2009), diphyllobothriideans (e.g., Poddubnaya 2002a, b), spathebothriideans (e.g., Poddubnaya et al. 2005a, b, 2007), and rhinebothriideans and tetraphyllideans (e.g., Reyda 2008).

Over half a century of work on the surface elaborations of cestodes has enhanced our understanding of these features to the point that standardisation of the terminology applied to these features is now in order. The term "microvillus" has been used in a number of different contexts in reference to the surface features of cestodes. In some cases, this term has been applied to structures that truly lack an electron-dense distal portion (e.g., MacKinnon and Burt 1984, Holcman and Heath, 1997). However, in other instances, the term has been applied to features that have actually been demonstrated to possess an electron-dense distal portion (e.g., Lee 1966, Holy and Oaks 1986), or, although examined only with SEM, likely possess an electron-dense distal portion (e.g., Whittaker et al. 1982). While some similarities exist between microvilli and microtriches, the distinctions between these two types of structures have been described in detail by a number of authors (e.g., Lumsden and Hildreth 1983, Holcman and Heath 1997). The structure of microtriches, most specifically their possession of an electron-dense cap, makes them unique among the cellular surface elaborations seen in animals. Thus, we believe these structures are justifiably referred to with the unique term microthrix (pl. microtriches).

\section{(1) Terminology for the components of a microthrix}

Fig. 1

The bipartite nature of microtriches, each consisting of a distal, electron-dense portion and a proximal, relatively electron-lucent portion, was recognised early in the literature. A diversity of terms has been used to describe the distal portion. These have included "tip" (e.g., Threadgold 1965), "spine” (Lee 1966), "spike” (e.g., Morseth 1967), “cap" (e.g., Charles and Orr 1968), "apex” (e.g., Mackiewicz 1972), and "shaft" (e.g., Jha and Smyth 1969), with the latter term gaining much popularity after the detailed treatment of Jha and Smyth (e.g., Hess and Guggenheim 1977, Coggins 1980, Thompson et al. 1980, Whittaker and Carvajal 1980, Granath et al. 1983, MacKinnon and Burt 1983, Beveridge and Smith 1985, Seif 1992). Terminology applied to the proximal, electron-lucent portion of a microthrix has been less variable, consisting primarily of "base" (e.g., Threadgold 1965) and "shaft" (e.g., Lee 1966). Unfortunately, the latter term also gained some popularity (e.g., Richards and Arme 1981a, Lumsden and

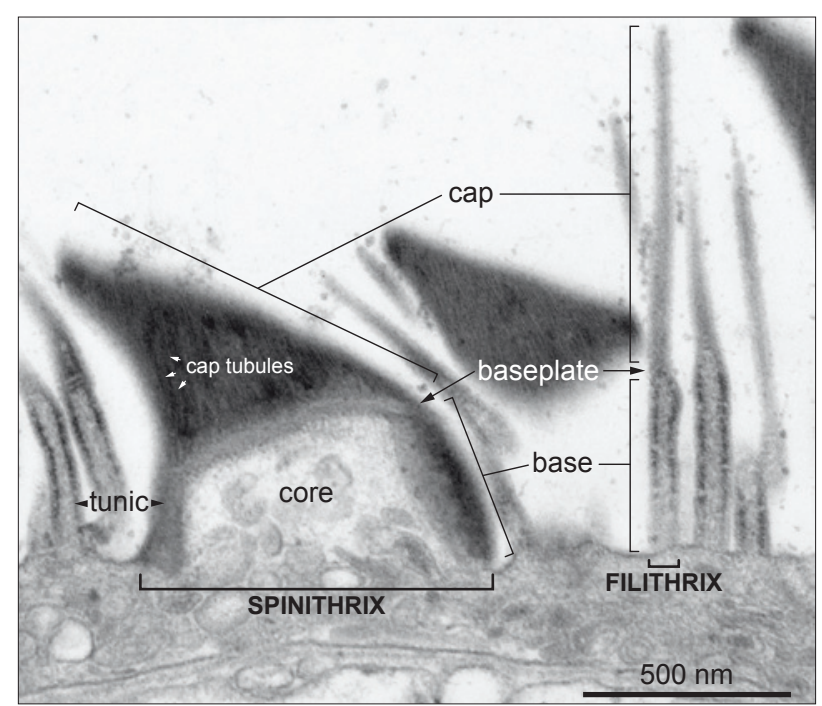

Fig. 1. Standardised terminology proposed for components of microtriches (filitriches and spinitriches). TEM through proximal surface of bothridium of Calliobothrium cf. verticillatum (Rudolphi, 1819). Note: base microfilaments and glycocalyx not shown.

Hildreth 1983, Threadgold and Dunn 1983, Threadgold 1984, Hildreth and Lumsden 1987, Smyth and McManus 1989, Lyngodoh and Tandon 1996), which has led to confusion with the same term having now been applied to both portions of a microthrix. The feature located at the boundary between the distal and proximal portions of a microthrix has been referred to as an "electron-lucid zone" (Threadgold 1965), a "tube-like structure" (e.g., Jha and Smyth 1969), a "junctional region" (e.g., Holy and Oaks 1986), and a multilaminate "baseplate" (e.g., Lumsden et al. 1974), with the latter term gaining some popularity (e.g., Hess and Guggenheim 1977, Thompson et al. 1980, Lumsden and Hildreth 1983, Richards and Arme 1984).

The terminology endorsed here for the components of a microthrix are summarised in Fig. 1. This terminology is generally consistent with that presented by Levron et al. (2008a). The distal, electron-dense portion of a microthrix should be referred to as the cap and the proximal, electron-lucent region should be referred to as the base. This avoids the issues associated with the dual application of the term "shaft" and is consistent with the terms for these regions applied by Holy and Oaks (1986) in their detailed treatment of microthrix architecture. We propose use of the term baseplate for the structure located at the boundary of the base and the cap. This term is in common use and is the simplest of the terms that have previously been applied to this feature. Following Holy and Oaks (1986), the filaments of the base should be referred to as microfilaments. The most appropriate term for the structures constituting the cap is more problematic for their identity in the realm of the cytoskeleton as microtubules, interme- 
diate filaments (i.e., keratin filaments), or microfilaments (i.e., actin-containing filaments) remains to be elucidated (J. Oaks, pers. comm.). However, as it has been shown that they are not actin-based (Holy and Oaks 1986), they should not be referred to as microfilaments (e.g., Levron et al. 2008a). In the interim, it would seem most appropriate to refer to them merely as cap tubules. For simplicity, we propose that the electron-dense sheath surrounding the electron-lucent core of the base should be referred to as a tunic, rather than a "core tunic" as suggested by Holy and Oaks (1986). The entire microthrix, including both the base and cap, is bounded by a plasma membrane, the external carbohydrate layer of which is termed the glycocalyx (not visible in Fig. 1).

\section{(2) Terminology for two basic microthrix types}

There is general consensus that, across cestode taxa, body regions, and developmental stages, microtriches commonly occur in two basic forms: a larger, more robust form, and a smaller, more slender form. Unlike the larger, more robust form, which can range, for example, from $0.33 \mu \mathrm{m}$ in width in Paraberrapex manifestus Jensen, 2001 (see Jensen 2001) to over $6.6 \mu \mathrm{m}$ in width, for example in Yorkeria izardi Caira, Jensen et Rajan, 2007 (see Caira et al. 2007a), the basal width of the smaller, more slender form appears to be rather conserved across taxa. Examples of reported ranges in the basal width of the more slender form include $0.12-0.19 \mu \mathrm{m}$ in Hymenolepis diminuta (see Rothman 1963, Lumsden and Specian 1980, Threadgold 1984), $0.1 \mu \mathrm{m}$ in two species of Diphyllobothrium Cobbold, 1858 (see Yamane 1968), $0.1 \mu \mathrm{m}$ in Gyrocotyle urna (Wagener, 1852) (see Lyons 1969), $0.2 \mu \mathrm{m}$ in Raillietina cesticillus (see Baron 1971), 0.08-0.09 $\mu \mathrm{m}$ in Mesocestoides corti Hoeppli, 1925 (see Hess and Guggenheim 1977), $0.166 \mu \mathrm{m}$ in Caryophyllaeus laticeps (Pallas, 1781) (see Richards and Arme 1981b), 0.12-0.16 in Bothriocephalus acheilognathi Yamaguti, 1934 (see Granath et al. 1983), $0.12 \mu \mathrm{m}$ in Haplobothrium globuliforme Cooper, 1914 (see Thomas 1983), $0.12 \mu \mathrm{m}$ in Phyllobothrium vagans Haswell, 1902 (see Beveridge and Smith 1985), $0.1 \mu \mathrm{m}$ in Taenia taeniaeformis (Batsch, 1786) (see Bortoletti and Ferretti 1985), $0.1 \mu \mathrm{m}$ in two species of Fimbria Froelich, 1802 (see Grytner-Zięcina et al. 1995), $0.1 \mu \mathrm{m}$ in Bombycirhynchus sphyraenaicum (Pintner, 1930) (see Palm et al. 1998), $0.1 \mu \mathrm{m}$ among cestodes in general (Caira et al. 1999, 2001), 0.065$0.167 \mu \mathrm{m}$ in Calliobothrium cf. verticillatum (Rudolphi, 1819) (see Fyler 2007). In fact, Fyler (2007) presented statistical evidence that a significant difference exists in the average basal width between the smaller, more slender microthrix form and the larger, more robust microthrix form in Calliobothrium cf. verticillatum.

Thus, with respect to a formal criterion that can be objectively applied to distinguish the smaller, more slender microthrix form from its larger, more robust counterpart, we propose that $0.2 \mu \mathrm{m}$ (i.e., $200 \mathrm{~nm}$ ) is an appropriate threshold base width. Options for the terms that might be applied to the two forms are many, and varied. For example, Berger and Mettrick (1971) referred to them as "conical" and "spathulate", Andersen (1975) as "slender" and "conical", Featherston (1975) as "slender and filamentous" and "broader spikes", Hess and Guggenheim (1977), Hess (1980), and Thompson et al. (1982) as "blade-like" and "filamentous", Gabrion and EuzetSicard (1979) as "lanceolated" and "filamentous", Voge et al. (1979) as "blade-shaped or conical" and "elongated slender" and, Kuperman (1988) as "tubular" and "coneshaped", Caira and Ruhnke (1990) as "spiniform microtriches" and "filiform microtriches" with one or both of the latter terms gaining some popularity throughout the 1990's (e.g., Ruhnke 1994a, 1996b, Ivanov and Campbell 1998b). Faliex et al. (2000) subsequently proposed that the latter terms be contracted as "spinithrix" and "filithrix", respectively. In the interest of developing as streamlined a terminology as possible, we propose formal adoption of spinithrix (pl. spinitriches) and filithrix (pl.filitriches) following Faliex et al. (2000). Thus, microtriches with basal widths of $\leq 200 \mathrm{~nm}$ should be considered to be filitriches; those with basal widths $>200 \mathrm{~nm}$ should be considered to be spinitriches.

\section{(3) Terminology of filithrix and spinithrix forms}

Figs. 2-9

Filitriches, and especially spinitriches, come in a wide variety of forms. This variation is most pronounced among major cestode taxa, but, as noted above, it has also been observed among regions of the body (in particular among regions of the scolex) and among developmental stages within individual species. Unfortunately, the terminology applied to describe variation in microthrix form has not kept pace with the discovery of microthrix variation. As a consequence, microthrix terminology has become somewhat unwieldy as terms have proliferated, and have been applied inconsistently across microthrix forms and cestode taxa. The terminology described below was designed to begin to remedy this situation.

It should be noted that the proposed terminology emphasises data generated from SEM over TEM. This is because, in the absence of relatively large numbers of serial sections, microthrix form is very difficult to assess using TEM alone. Interpretation of form can vary depending on the angle of the section taken; in many cases, the specifics of a form (e.g., the distribution of marginal and/or dorsoventral projections) are impossible to determine without the aid of SEM. In addition, perhaps because SEM is faster and easier to employ than TEM, SEM data are currently available for a much broader spectrum of taxa than are TEM data. Thus, the terminology proposed here does not take into account internal microthrix features such as the 
- FILITRICHES ( $\leq 200 \mathrm{~nm}$ in width)

\begin{tabular}{|l|l|}
\cline { 2 - 3 } \multicolumn{1}{c|}{} & \multicolumn{1}{c|}{ LENGTH } \\
\hline DUPLICATION (optional) & $\begin{array}{l}\text { papilliform } \\
\text { (Figs. 3A, B, 4M, O, 7A, P, S) } \\
\text { duplicated } \\
\text { (Fig. 3P) }\end{array}$ \\
\cline { 2 - 2 } & $\begin{array}{l}\text { acicular } \\
\text { (Figs. 3C-I, P, 4B, C, 5K, 6F, P, 7C) } \\
\text { capilliform } \\
\text { (Figs. 3I-O, 4K, 5D-I, 6A-C, 7L-N) }\end{array}$ \\
\hline
\end{tabular}

Examples of filithrix terminology:

$$
\begin{array}{r}
\text { acicular filithrix } \\
\text { (Figs. 3C-I) }
\end{array}
$$

duplicated acicular filithrix

(Fig. 3P)

\section{- SPINITRICHES (>200nm in width)}

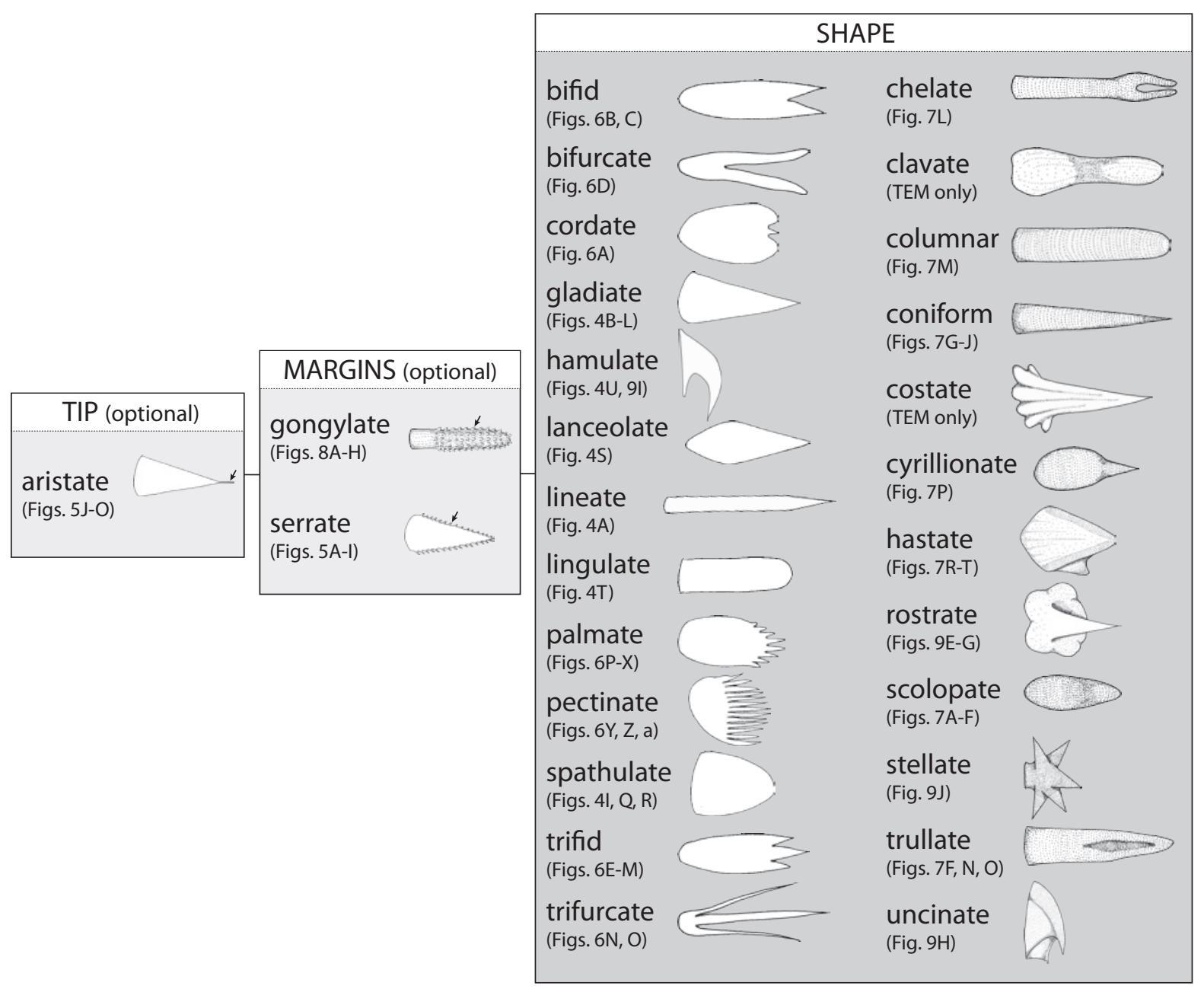

Examples of spinithrix terminology:
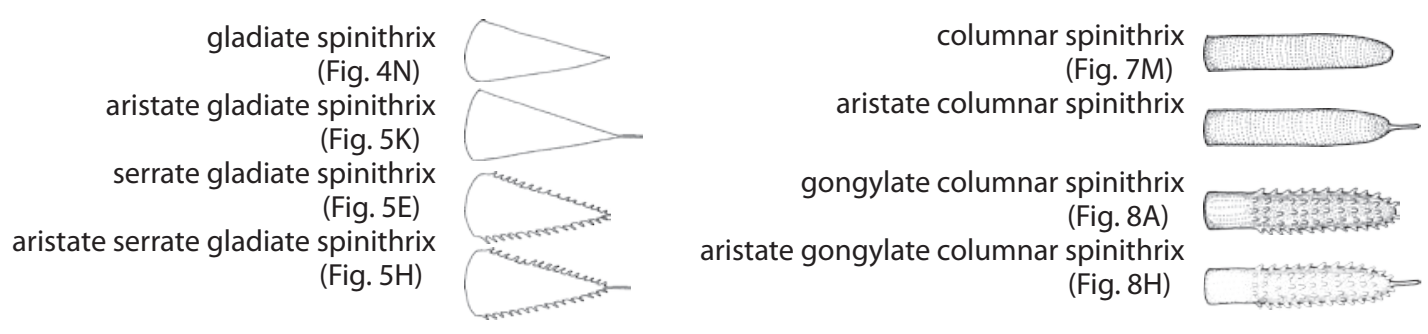

Fig. 2. Schematic representation of terms proposed to describe filithrix (upper panel) and spinithrix (lower panel) forms. Dark grey boxes indicate mandatory descriptors; lighter grey boxes indicate those used only when applicable. 
extent of the electron-dense cap or the configuration of the electron-dense tunic (if any) surrounding the core, both of which have been shown with TEM to vary somewhat among taxa (e.g., Palm 2004). Nonetheless, it is our hope that TEM data will ultimately be generated for the variety of microthrix forms articulated below, providing additional information to test the circumscription of these forms.

With respect to illustrating the proposed terminology, we have taken two different approaches. Fig. 2 summarises this terminology and serves as a quick reference to facilitate application of these terms. This figure presents schematic representations of the three conditions of filithrix length, and the 25 spinithrix shapes, and their apical (tip) and marginal and/or dorsoventral modifications. It also illustrates several examples of the application of these terms. In addition, SEM images illustrating as much of the proposed terminology as possible are provided in Figs. 3-9. In most cases, we have provided multiple examples of each form in order to illustrate what we consider to be acceptable variation within a particular form. However, to conserve space, Fig. 2 refers to only subsets of the SEM images in Figs. 3-9.

\section{FILITHRIX TERMINOLOGY}

(applied to microtriches with basal widths of $\leq 200 \mathrm{~nm}$ )

Figs. 2, 3

Historically, only a few authors have gone beyond acknowledging the existence of filitriches, to recognising specific forms of filitriches. Thus, only a few terms exist as options to adopt for describing variation in filithrix form. Nonetheless, much confusion exists in the application of the limited array of available terms. In many cases the term "filiform" appears to have been used to refer to the more elongate filithrix form (e.g., Hoberg et al. 1995, de Chambrier et al. 2008, 2009a, b, de Chambrier and Scholz 2008), which appears to be the most commonly encountered and ubiquitous form. Following examination of multiple litobothriidean, cathetocephalidean, diphyllidean, trypanorhynch, rhinebothriidean, and tetraphyllidean taxa, Caira et al. $(1999,2001)$ recognised two distinct forms of filitriches, short and long, distinguishing between these two forms on the basis of whether their length was equal to, or greater than, their basal width. These authors employed the terms "short filiform microthrix" and "long filiform microthrix," respectively to these two forms. Hoberg et al. (1995) referred to a "papilliform" microthrix, which appears to be consistent with the short filiform microthrix of Caira et al. (1999, 2001). The term "small filiform microthrix" has been used to describe filitriches seen in proteocephalideans (e.g., de Chambrier et al. 2008) and bothriocephalideans (e.g., Kuchta et al. 2008a, 2009). However, examination of the images of the latter authors suggests that this form may actually be intermediate in length between the shortest and longest forms seen by previous authors such as
Hoberg et al. (1995) and Caira et al. (1999). Palm (2004) provided the most detailed treatment of filithrix forms to date. He presented four terms for referring to filitriches, depending on a combination of filithrix length and extent of the electron-dense cap. These forms consisted of "papillate", "aciculate", "capilliform", and "filiform".

In general, variation in filithrix form is relatively straightforward when compared to that seen among spinitriches. Filitriches vary primarily in length. The terminology proposed here accommodates the three basic filithrix lengths observed to date. The fact that some filitriches bear pointed tips and others bear rounded tips has not been incorporated into the proposed terminology. Also not incorporated at this time is the degree of flexibility exhibited by filitriches; some are consistently stiff (e.g., Fig. 3F), whereas others are remarkably flexible (e.g., Fig. 3M). In the cases of both tip form and degree of flexibility, this is because we believe that the extent of the electron-dense cap may have a bearing on these aspects of filithrix form, and are thus hesitant to develop a terminology to accommodate these types of variation in the absence of more extensive TEM data. As a consequence, while we have adopted some elements of the terminology of Palm (2004), we have not endorsed all elements. In addition, the forms of the terms used here deviate somewhat from those of Palm (2004), so as to be more correct with respect to their derivation from Greek or Latin. So, for example, we have modified the term papillate (L., covered with papillae) to papilliform (L., shaped like a papilla), etc. The proposed terminology also recognises the fact that filitriches can be duplicated, or even in rare cases, triplicated, at their bases.

\section{Filiform microthrix length}

(i) Papilliform (shaped like a papilla) (papilla; L., nipple) Figs. 2, 3A, B, 4M, O-R, 6H, X-Z, a, 7A, P, S

This is the shortest of the filithrix forms. This term applies to filitriches that are up to two times as long as they are wide. That these minute structures represent true microtriches, a fact assumed by Caira et al. (1999), was convincingly demonstrated by Fyler (2007), who provided detailed evidence from TEM that they possess all of the elements (e.g., electron-dense cap, etc.) of true microtriches. These structures are typical, for example, of the distal bothridial surfaces of multiloculate onchobothriid tetraphyllideans (e.g., Caira 1990b, Fyler and Caira 2006, Reyda and Caira 2006); they have also been observed in a diversity of trypanorhynchs (e.g., Palm 2004).

(ii) Acicular (shaped like a small pin) (acicula; L., small pin, needle)

Figs. 2, 3 C-I, P, 4B, C, J, N, T, 5K, 6F, P-S, V, W, 7C, G, K, Q, R, T

This term applies to filitriches that are $>2$ to 6 times as long as they are wide. These structures have been found, for example, on the distal bothridial surfaces of a diver- 

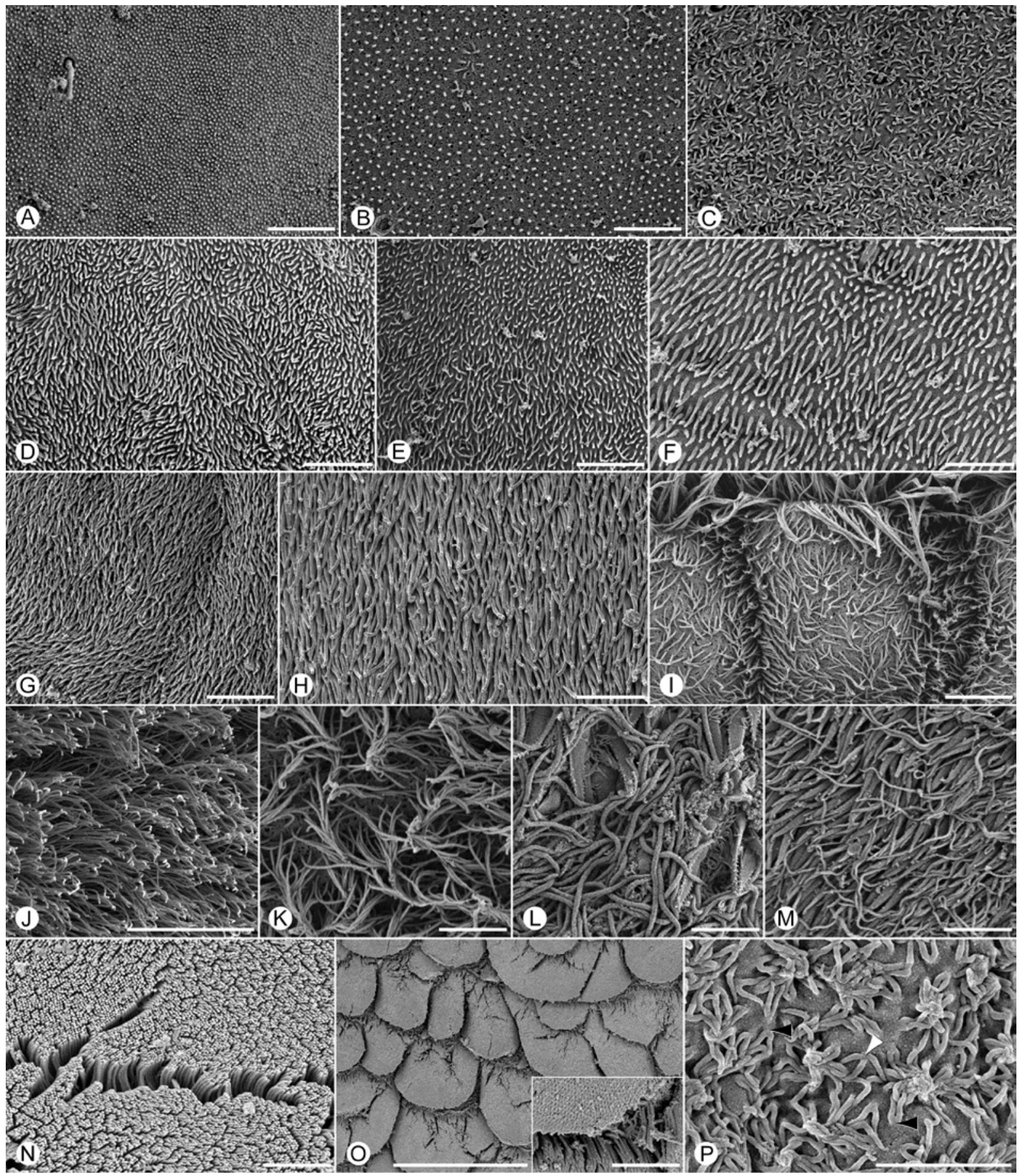

Fig. 3. Scanning electron micrographs illustrating filitriches. A - Distal bothridial surface of Acanthobothrium marymichaelorum; papilliform filitriches. B - Apical region anterior to hooks of bothridium of Yorkeria garneri; papilliform filitriches. C - Anterior region anterior to hooks of bothridium of Yorkeria garneri; acicular filitriches. D - Distal bothridial surface of Anthocephalum centrurum; acicular filitriches. E - Proximal surface of bothridial apical sucker of Anthocephalum centrurum; acicular filitriches. F - Laciniation of proglottid of Litobothrium janovyi; acicular filitriches. G - Scolex proper of Lecanicephalum sp.; acicular filitriches. H - Distal region of scolex of Caryophyllaeus laticeps; acicular filitriches. I - Proximal surface of bothridial marginal loculus of new tetraphyllidean genus from Himantura pastinacoides; acicular and capilliform filitriches. J - Strobila of Cyathocephalus truncatus; capilliform filitriches. K - Apical region of bothridium anterior to hooks of Megalonchos sumansinghai; capilliform filitriches. $\mathbf{L}$ - Distal bothridial surface of Orygmatobothrium sp.; capilliform filitriches and serrate spinitriches. M - Proximal surface of sucker of Proteocephalus perplexus; capilliform filitriches and coniform spinitriches. $\mathbf{N}$ - Strobila of Anthocephalum cairae; capilliform filitriches. $\mathbf{O}$ - Strobilar scutes of Orectolobicestus tyleri; inset detail shows scutes composed of capilliform filitriches. P - Fourth cruciform pseudosegment of Litobothrium janovyi; duplicated acicular filitriches (black arrowhead) and triplicated acicular filitriches (white arrowhead). Scale bars: Figs. A-I, K-N, inset in $\mathrm{O}, \mathrm{P}=2 \mu \mathrm{m} ; \mathrm{Figs} . \mathrm{J}, \mathrm{O}=10 \mu \mathrm{m}$. 
sity of tetraphyllideans (e.g., Ruhnke 1994a, Caira et al. 2007b), rhinebothriideans (e.g., Healy 2006a, b), litobothriideans (e.g., Olson and Caira 2001), and lecanicephalideans (e.g., Jensen 2005).

(iii) Capilliform (thread or hair-like in form) (capillus; L., hair) Figs. 2, 3I-O, 4K, 5A, B, D-I, L, N, O, 6A-C, E, K, L, T, U, 7H, L-N, U, 9A, C-H

This is the longest of the filithrix forms. This term is applied to filitriches that are $>6$ times as long as they are wide. However, in most cases, the length of this form of filithrix greatly exceeds six times its width. While all are $<200 \mathrm{~nm}$ in diameter, there appears to be some variation in the width of this filithrix form in some taxa (e.g., Orygmatobothrium, Fig. 3L). This is the most commonly reported form of filithrix to date. It has, for example, been observed on various regions of the scolex in a diversity of tetraphyllideans (e.g., Caira et al. 1999, 2001), proteocephalideans (e.g., Scholz et al. 1999), and diphyllideans (e.g., Ivanov and Campbell 1998a). This is also the filithrix form seen throughout the strobila of most cestode species. Furthermore, as noted, for example, by Ruhnke (1994a), Ruhnke et al. (2006a, b), Ivanov (2008) and Ruhnke and Carpenter (2008), the "scutes" described on the "neck" and strobila of tetraphyllidean genera such as Paraorygmatobothrium Ruhnke, 1994, Orectolobicestus Ruhnke, Caira et Carpenter, 2006, and Orygmatobothrium Diesing, 1863, respectively, actually consist of dense arrangements of these filitriches (see Fig. $3 \mathrm{O}$ and corresponding inset).

The typical highly dense arrangement of filitriches, and of capilliform filitriches in particular, leaves much to be learned about the bases of these structures. While there are a number of instances in which no specific basal elaborations have been seen in capilliform filitriches (e.g., Fig. 3K), laterally extended bases have been observed in other instances (e.g., Fig. 9A).

\section{Duplication}

Duplicated (doubled at its base)

Figs. 2, 3P

This term should be applied to identical filitriches that arise from a common base. This form is difficult to categorise correctly if the base is not visible. Although this appears to be a relatively rare condition, duplicated filitriches of the acicular type have been reported on the strobila of litobothriideans (e.g., Olson and Caira 2001, black arrowhead in Fig. 3P). In such instances we propose the use of the term "duplicated" prior to the term describing the length of the filithrix. However, given how unusual this condition appears to be, we propose that in the absence of use of this modifier, a microthrix should be assumed to be single. It is easy to envision multiples of greater than two filitriches occurring in some cestode taxa. In such cases, variations on this term should be employed. So, for example, instances of three filitriches aris- ing from a single base (e.g., white arrowhead in Fig. 3P) would be considered to be triplicated, and so on.

\section{SPINITHRIX TERMINOLOGY}

(applied to microtriches with basal widths $>200 \mathrm{~nm}$ )

Figs. 2-9

Owing to the much greater degree of morphological variation seen in spinitriches, a much greater number of terms has historically been employed to describe the diversity of spinithrix forms observed to date. Once again, however, these terms have not necessarily been uniformly applied and it has not been uncommon for several different terms to be proposed to describe the same spinithrix form, even by the same author. For example, triangular spinitriches were referred to as "spiniform microtriches" by Ghoshroy and Caira (2001), as "bladelike spinitriches" by Caira and Tracy (2002) and as "gladiate spinitriches" by Caira et al. (2007a, b). On many occasions, authors have adopted new terms as required to describe unusual morphologies they have encountered. So, for example, Halton and McKerr (1979) referred to the unusual, large multidigitate microthrix form seen in the trypanorhynch Grillotia erinaceus (van Beneden, 1849) as "palmate". Thompson et al. (1980) recognised "peg-like", "bladelike", and "spine-like" variations of the larger microthrix type in the proteocephalidean they examined. Whittaker and Carvajal (1980) referred to the spinitriches seen in the tetraphyllidean Orygmatobothrium musteli (van Beneden, 1849) as having an "ear-of-corn" appearance. Caira et al. (1999) later formalised this concept with their use of the term "maiziform". On only two occasions have sets of terms been proposed to describe the overall variation seen in spinitriches. Caira et al. $(1999,2001)$ developed a series of standard modifiers to describe variations in form of spinitriches. These consisted of "blade-like", "serrate", "maiziform", "pectinate", and "tridentate". Similarly, in his monograph on trypanorhynchs, Palm (2004) provided a relatively detailed treatment of terminology of microtriches guided to some extent by the group discussion of microthrix forms that occurred at the 4th International Workshop on Cestode Systematics in Storrs, Connecticut, USA, and recognised spinitriches of the following forms: gladiate, serrate, pectinate, palmate, tricuspidate, mucronate, aristate, lingulate, and bifurcate. However, even these terms have not been used consistently.

The terminology presented here for spinitriches builds on the schemes of Caira et al. $(1999,2001)$ and Palm (2004), both originally developed primarily for microtriches observed in elasmobranch cestodes. However, the present work represents a much more thorough treatment in that it attempts to accommodate variation seen in microtriches across all major cestode taxa.

Our review of spinithrix form suggests that the variation seen to date may be captured in a series of three modifiers, one describing overall shape, one addressing 

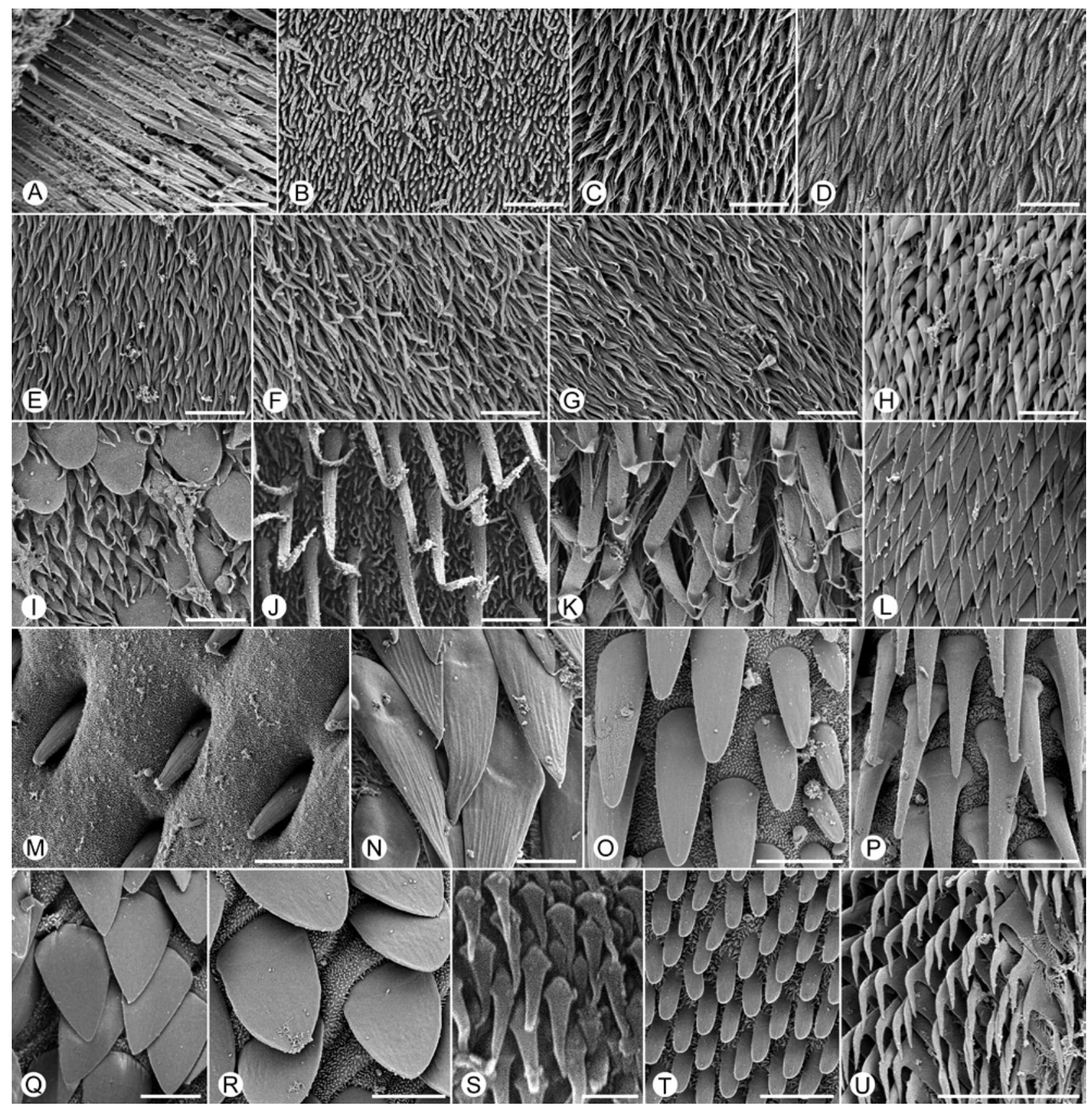

Fig. 4. Scanning electron micrographs illustrating some shapes of spinitriches in which width greatly exceeds thickness. A - Medial edge of distal bothrial surface of Heteronybelinia estigmena; lineate spinitriches. B - Laciniation of fourth pseudosegment of Litobothrium amplifica; small gladiate spinitriches and acicular filitriches. C - Scolex proper of Paraberrapex manifestus; small gladiate spinitriches and acicular filitriches. D - Strobila of Proteocephalus perplexus; small gladiate spinitriches. E - Strobila of Tetrabothrius cylindraceus; small gladiate spinitriches. F - Distal region of scolex of Khawia sinensis; small gladiate spinitriches. G - Distal surface of sucker of Echinococcus granulosus; small gladiate spinitriches. H - Strobila of Progynotaenia odhneri; gladiate spinitriches. I - Distal acetabular surface of Eniochobothrium euaxos; gladiate and spathulate spinitriches. J - Proximal bothridial surface of Ceratobothrium xanthocephalum; narrow gladiate spinitriches and acicular filitriches. $\mathbf{K}$ - Distal surface of anterior of bothridial loculus of Megalonchos sumansinghai; narrow gladiate spinitriches and capilliform filitriches. $\mathbf{L}-\mathrm{Cephalic}$ peduncle of Erudituncus sp.; gladiate spinitriches. M - Lateral region of proglottid of Gastrolecithus planus; gladiate spinitriches and papilliform filitriches. $\mathbf{N}$ - Pedicel of bothridial pair of Yorkeria kelleyae; aristate gladiate spinitriches and acicular filitriches. $\mathbf{O}$ - Proximal bothridial surface of Yorkeria teeveeyi; gladiate spinitriches and papilliform filitriches. P-Peduncle of Phoreiobothrium lewinensis; gladiate spinitriches and papilliform filitriches. $\mathbf{Q}$ - Pedicel of bothridial pair of Yorkeria saliputium; spathulate spinitriches and papilliform filitriches. $\mathbf{R}$ - Pedicel of bothridial pair of Yorkeria izardi; spathulate spinitriches and papilliform filitriches. S - Strobila of Tetrabothrius lutzi; lanceolate spinitriches. T - Distal surface of post-hook loculus in Yorkeria izardi; lingulate spinitriches and acicular filitriches. $\mathbf{U}$ - Margin of bothrium in Heteronybelinia estigmena; hamulate spinitriches and capilliform filitriches. Scale bars: Figs. A-L, $N=2 \mu \mathrm{m}$; Figs. M, U = $10 \mu \mathrm{m}$; Figs. O, Q, R, T = 5 $\mu$; Fig. P=20 $\mu \mathrm{m} ;$ Fig. $\mathrm{S}=1 \mu \mathrm{m}$. 
marginal and/or dorsoventral elaborations, and one addressing apical features. Thus we have separated the description of apical and marginal and/or dorsoventral modifications, such as serrations, from the terms used to describe the form of the structure. We propose that these three sets of modifiers be used consistently, in the following sequence as appropriate: apical elaborations, marginal and/or dorsoventral modifications, and basic shape. Given their relative rarity, we suggest that the modifiers describing apical and marginal and/or dorsoventral modifications should be used only if applicable. Thus, in the absence of a marginal and/or dorsoventral modifier, a spinithrix should be considered to possess smooth margins. Similarly, a spinithrix should be assumed to lack an apical modification if the apical modifier is not used. We recognise 25 spinithrix shapes. In determining the appropriate term to apply to a shape, it is helpful to consider both the basic form and whether the width of a spinithrix greatly exceeds its thickness. In Fig. 2, those forms in which the width greatly exceeds the thickness are shown in the left column in the spinithrix shape panel and those forms in which the width is approximately equal to the thickness are shown in the right column in that panel. In the description of spinithrix forms that follows, forms in which width greatly exceeds thickness are presented first, and in alphabetical order. These are followed by descriptions of spinithrix forms in which width and thickness are approximately equal, again, in alphabetical order. The section describing spinithrix shape is followed by a section describing modifiers proposed for marginal and then dorsoventral, elaborations. Lastly, apical modifiers are described.

Wherever possible we have adopted terms used previously. For forms to which multiple terms have been applied, we have generally advocated the use of the simplest, most descriptive term. For microthrix forms for which terms do not already exist, we have chosen terms that have their origins in Latin or Greek, which describe the form of the microthrix as closely as possible.

\section{Overall shape}

\section{A. Spinitriches in which width greatly exceeds thickness

(i) Bifid (shallowly forked) (bifidus; L., double)

Figs. 2, 6B, C

These spinitriches possess relatively short prongs, which do not comprise more than half the length of the spinithrix. The component parts, or prongs, can be paral- lel to one another, converge on one another (e.g., Fig. 6B), or they can diverge from one another (e.g., Fig. 6C). The prongs may be equal or unequal to one another in width; similarly, the prongs may be equal or unequal to one another in length.

(ii) Bifurcate (deeply forked) (bifurcus; L., two-pronged) Figs. 2, 6D

The two prongs of bifurcate spinitriches are relatively long, comprising greater than half the length of the spinithrix. This form appears to be relatively uncommon. To date it has been observed only on the margins of the bothria of certain otobothriid trypanorhynchs (e.g., see Palm 2004)

(iii) Cordate (heart-shaped) (cordatus; L., heart-shaped)

Figs. 2, 6A

These spinitriches are classically heart-shaped. We propose that this term be used regardless of whether the terminal notch bears a point. At present, this form has been observed only in a small subset of rhinebothriidean taxa (e.g., Healy 2006b).

\section{(iv) Gladiate (sword-shaped) (gladius; L., sword)}

Figs. 2, 4B-P, 5A-N

These spinitriches are broadest at their bases, taper to a point, and possess sides that are straight, rather than concave or convex. This is one of the most commonly encountered forms of spinithrix, having been observed in members of a wide spectrum of cestode orders including trypanorhynchs, rhinebothriideans, tetraphyllideans, proteocephalideans, and cyclophyllideans. This form varies greatly in size (e.g., compare Figs. 4B-H to Figs. 4N-P) and in the relative proportions of width to length (e.g., compare Figs. $4 \mathrm{~J}$ and $\mathrm{K}$ to Figs. $4 \mathrm{~N}$ and $\mathrm{O}$ ). At this point, we have not proposed a formal scheme for the recognition of either of these differences. Such differences could be accommodated by use of the terms small and large or narrow and wide at the beginning of the string of modifiers. However, we suggest that such additional modifiers be used sparingly.

\section{(v) Hamulate (hook-shaped) (hamulus; L., hook)}

Figs. 2, 4U, 9I

These spinitriches are normally oriented perpendicular to the surface of the tegument so that, unlike most other spinitriches, they appear to be laterally, rather than dorsoventrally, flattened. They are unusual in that they are much thicker than they are wide. These spinitriches possess a relatively broad base and are recurved distally. These are the "hooklike" spinitriches of Palm (2004), who noted that the ultrastructure of these forms differs

Fig. 5. Scanning electron micrographs illustrating marginal and apical modifications of some spinithrix forms in which width greatly exceeds thickness. A - Proximal bothridial surface of Orectolobicestus mukahensis; serrate gladiate spinitriches and capilliform filitriches. B - Distal bothridial surface of Orectolobicestus tyleri; serrate gladiate spinitriches and capilliform filitriches. $\mathbf{C}-\mathrm{Pe}-$ duncle of Paraorygmatobothrium sp.; serrate gladiate spinitriches. D - Distal bothridial surface of Paraorygmatobothrium janinae; serrate gladiate spinitriches and capilliform filitriches. E - Proximal bothridial surface of Ruhnkecestus latipi; serrate gladiate 

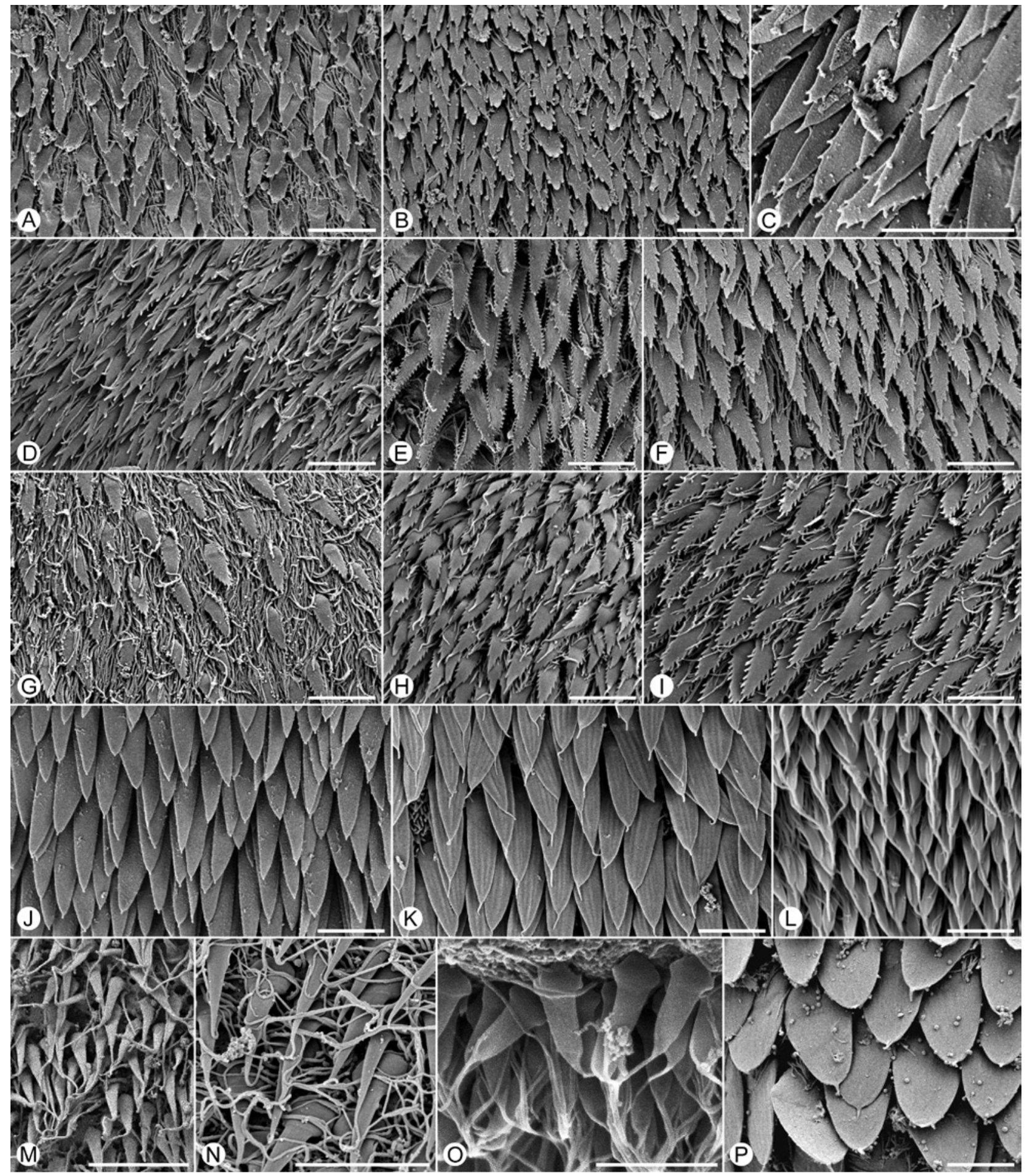

spinitriches and capilliform filitriches. F - Proximal bothridial surface of Orectolobicestus lorettae; serrate gladiate spinitriches and capilliform filitriches. G - Lateral portion of apical sucker of Orectolobicestus lorettae; serrate gladiate spinitriches and capilliform filitriches. $\mathbf{H}$ - Proximal surface of bothridium of Paraorygmatobothrium sp.; aristate serrate gladiate spinitriches and a few capilliform filitriches. I - Proximal bothridial surface of Paraorygmatobothrium janinae; serrate gladiate spinitriches and capilliform filitriches. J - Cephalic peduncle of Megalonchos sumansinghai; aristate gladiate spinitriches. $\mathbf{K}$ - Pedicel of bothridial pair of Spiniloculus sp.; aristate gladiate spinitriches and acicular filitriches. L - Distal bothrial surface of Prochristianella sp.; aristate gladiate spinitriches and capilliform filitriches. $\mathbf{M}$ - Distal surface of anterior loculus of bothridium of new tetraphyllidean genus from Parascyllium collarae; aristate gladiate spinitriches. $\mathbf{N}$ - Distal bothridial surface of Anthobothrium caseyi; aristate gladiate spinitriches and capilliform filitriches. $\mathbf{O}$ - Strobila of Tetrabothrius lutzi; aristate lanceolate spinitriches. $\mathbf{P}$ - Proximal bothridial surface of new tetraphyllidean genus from Himantura cf. gerrardi; aristate spathulate spinitriches and capilliform filitriches. Scale bars $=2 \mu \mathrm{m}$. 
substantially from that seen in other spinitriches. For example, they lack a baseplate and the electron-dense portion of the structure appears to be embedded within the outer layer of the tegument, rather than to be associated with an electron-lucent extension of the tegument. In fact, it is possible that these structures are not microtriches at all. Nonetheless, we have included them here, and among the microthrix forms that are greater in diameter in one dimension than in the other, until such time as their structure can be studied in more detail. This form has been observed on the margins of the bothria of trypanorhynch families such as the Tentaculariidae (see Palm 2004); they have also been observed on the cirrus of some cyclophyllideans (e.g., Fig. 9I).

(vi) Lanceolate (narrowing at both ends) (lanceola; L., a light spear, lance)

Figs. 2, 4S

This term is proposed for spinitriches that taper both at their base and their tip and that are thus widest slightly behind their midpoint. This microthrix form is infrequently encountered, but has been observed on the strobila of the tetrabothriidean Tetrabothrius lutzi Parona, 1901 (Ivanov pers. comm.).

(vii) Lineate (resembling a line) (lineatus; L., of a line, linear)

Figs. 2, 4A

This spinithrix form is conspicuously narrow, possessing sides that are parallel to one another throughout most of their length. However, this spinithrix tapers relatively abruptly to a sharp point. This is a rare form, known to occur in some tentaculariid trypanorhynchs (e.g., Palm 2004).

(viii) Lingulate (shaped like a tongue) (lingua; L., tongue)

Figs. 2, 4T

This spinithrix form also possesses sides that are generally parallel to one another, but the structure is rounded at its tip. This form has been observed in several different onchobothriid (i.e., tetraphyllidean) genera (e.g., Caira 1992, Caira et al. 2004, 2007a).

(ix) Palmate (having lobes radiating from the margins; resembling an open hand) (palma; L., palm of the hand)

Figs. 2, 6P-X

Palmate spinitriches possess more than three prongs that originate at different points relative to one another, and that also terminate at different points relative to one another. As a consequence, the prongs are often unequal in length. The prongs can be short relative to the length of the spinithrix (e.g., Figs. 6Q, T, U) or long (e.g., Figs. $6 \mathrm{R}, \mathrm{S}, \mathrm{V}, \mathrm{W}, \mathrm{X})$. The prongs are generally of equal width. The number of prongs varies from a minimum of 4 (e.g., Fig. 6Q) to at least 11 (Fig. 6X). We recommend that these variations on the basic palmate spinithrix theme, including the number of prongs, be included in the description of the microthrix form. Thus, for example, terms such as quadridigitate, pentadigitate, hexadigitate, may be employed to describe the number of prongs. In some cases, the surface of palmate spinitriches is smooth (e.g., Figs. $6 \mathrm{Q}, \mathrm{V}, \mathrm{X})$, in other cases, the surface bears superficial ribbing (e.g., Figs. 6T, U). The fact that the ribs are continuous with the prongs in some cases (e.g., Fig. 6T) suggests that palmate spinitriches may be comprised of fused filitriches. However, this will require TEM to resolve. Palmate spinitriches are commonly found on the scolex of trypanorhynchs (e.g., Palm 2004) and diphyllideans (e.g., Tyler 2006).

(x) Pectinate (having projections resembling the teeth of a comb) (pectinatus; L., comb-like) Figs. 2, 6Y, Z, a, b

Pectinate spinitriches possess more than three prongs arranged parallel to one another. The prongs originate at approximately the same point relative to one another, and also terminate at approximately the same point relative to one another. As a consequence, the prongs are approximately equal in length. To date, variation in the number of prongs ranges from 9 to 16 (e.g., Fig. 6Y). The prongs are generally of equal width. These microtriches have been reported from diphyllideans (see Tyler 2006).

It appears that a variation on the pectinate spinithrix theme may occur in some cathetocephalideans. A meandering series of structures, each of which appears to bear numerous short prongs, at least when viewed distally, giving them the appearance of pectinate spinitriches, was observed on the middle region of the base of the scolex of Cathetocephalus resendezi Caira, Mega et Ruhnke, 2005 by Caira et al. (2005) (Fig. 6b). These structures differ in orientation from typical pectinate spinitriches in that they appear to be oriented essentially perpendicular, rather than parallel, to the surface. They are very densely arranged and even in a single region can vary substantially in width

Fig. 6. Scanning electron micrographs illustrating some spinithrix forms in which width greatly exceeds thickness. A - Proximal bothridial surface and stalks of new genus of rhinebothriidean; cordate spinitriches and capilliform filitriches. B - Apex of scolex just below tentacle of Hornelliella annandalei; bifid spinitriches and a few capilliform filitriches. $\mathbf{C}$ - Margin of bothrium of Hornelliella annandalei; bifid spinitriches and capilliform filitriches. D - Bothrial rim of Otobothrium mugilis; bifurcate and trifid spinitriches. E - Pars vaginalis of Paroncomegas areiba; trifid spinitriches and capilliform filitriches. F - Pars vaginalis of Dolfusiella sp.; trifid spinitriches and acicular filitriches. G - Proximal bothridial surface Orectolobicestus randyi; trifid spinitriches and capilliform filitriches. $\mathbf{H}$ - Proximal bothrial surface of Paragrillotia similis; trifid spinitriches and papilliform filitriches. I - Distal surface of sucker of Progynotaenia odhneri; trifid spinitriches. $\mathbf{J}$ - Pars vaginalis of Callitetrarhynchus gracilis; trifid spinitriches. $\mathbf{K}$ - Distal bothrial surface of Callitetrarhynchus gracilis; trifid spinitriches and capilliform filitriches. $\mathbf{L}$ - Distal bothrial surface of Lacistorhynchus tenuis; trifid spinitriches and capilliform filitriches. $\mathbf{M}$ - Proximal bothrial surface of Echinobothrium mexicanum; trifid spinitriches. $\mathbf{N}$ - Medial distal bothrial surface of Echinobothrium euterpes; trifurcate spinitriches. $\mathbf{O}$ - Distal 

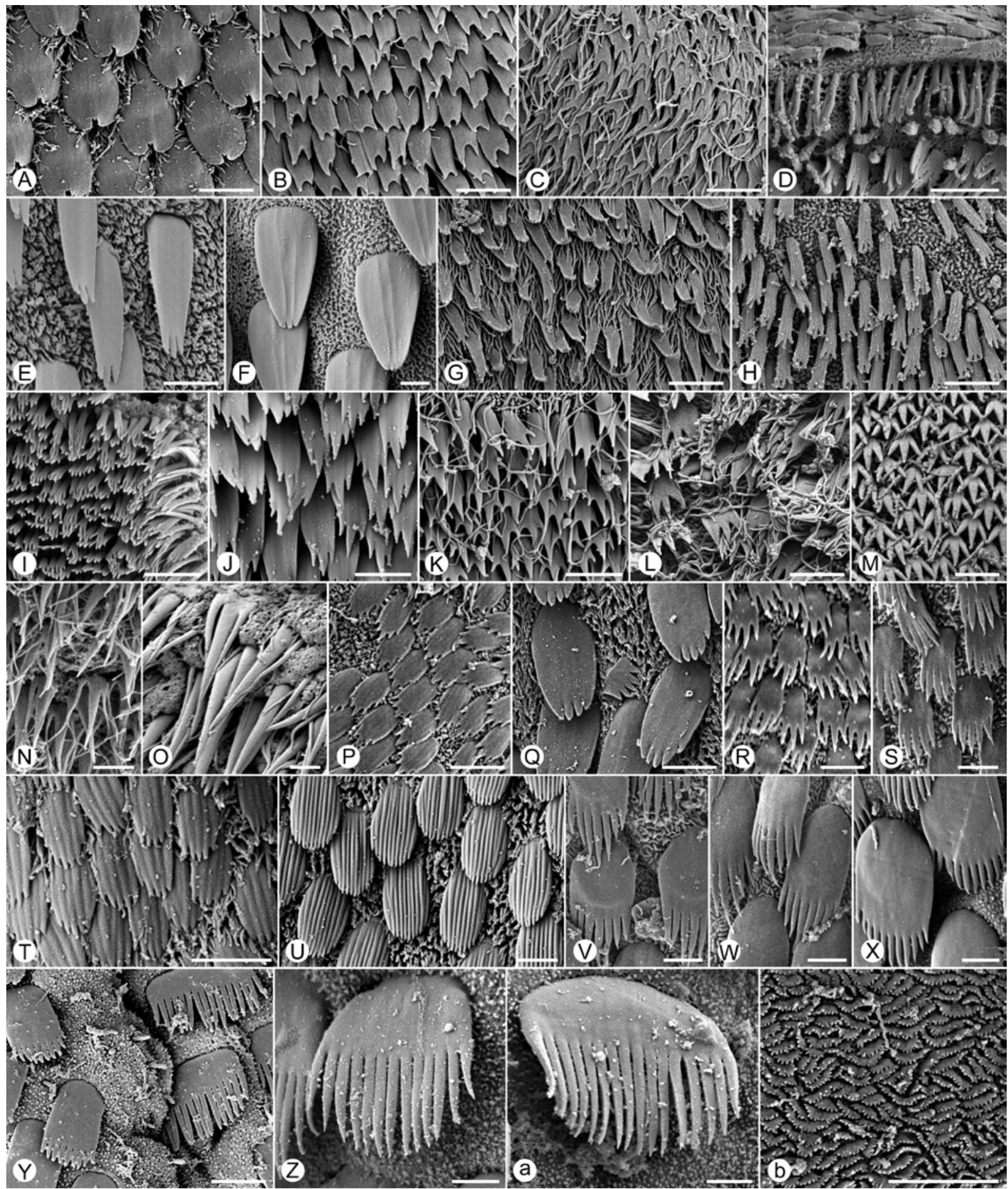

bothrial surface of Ditrachybothridium macrocephalum; trifurcate spinitriches. P - Proximal bothrial surface of Lacistorhynchus tenuis; palmate spinitriches and acicular filitriches. $\mathbf{Q}$ - Interbothrial region of eutetrarhynchid; palmate spinitriches and capilliform filitriches. $\mathbf{R}$ - Lateral surface of scolex proper of Echinobothrium rayallemangi; palmate spinitriches and acicular filitriches. $\mathbf{S}$ - Proximal bothrial surface of Echinobothrium elegans; palmate spinitriches and acicular filitriches. T - Proximal bothrial surface of Prochristianella sp.; palmate spinitriches and capilliform filitriches. U - Pars vaginalis of Prochristianella sp.; palmate spinitriches and capilliform filitriches. V - Posterior proximal bothrial surface of Echinobothrium euterpes; palmate spinitriches and acicular filitriches. W - Anterior proximal bothrial surface of Echinobothrium euterpes; palmate spinitriches and acicular filitriches. $\mathbf{X}$ - Proximal bothrial surface of Echinobothrium rayallemangi; palmate spinitriches and papilliform filitriches. Y - Proximal bothrial surface of Echinobothrium hoffmanorum; pectinate spinitriches and papilliform filitriches. $\mathbf{Z}$ - Distal bothrial surface of Echinobothrium rayallemangi; pectinate spinithrix and papilliform filitriches. a-Mediodistal bothrial surface of Echinobothrium hoffmanorum; pectinate spinithrix and papilliform filitriches. b - Middle region of base of scolex of Cathetocephalus resendezi; possible modified pectinate spinitriches. Scale bars: Figs. A-L, P, Q, T, U, Y, b $=2 \mu \mathrm{m}$; Figs. M-O, R, S, V-X, Z, a $=1 \mu \mathrm{m}$. 
and also in the total number of "prongs". Some appear to bear over 20 of such "prongs", however, the prong-like structure of these features remains to be confirmed.

(xi) Spathulate (resembling a broad blade) (spatha; L., broad blade)

Figs. 2, 4I, Q, R

These spinitriches possess a conspicuously broad base and sides that are slightly (e.g., Fig. 4Q) or conspicuously (e.g., Fig. 4R) convex; they taper distally to an inconspicuous point. This form is commonly seen in tetraphyllideans such as Yorkeria Southwell, 1927 (e.g., Caira and Tracy 2002).

(xii) Trifid (divided into three relatively short parts) (trifidus; L., three-cleft)

Figs. 2, 6E-M, 7L

The three prongs of trifid spinitriches are relatively short, comprising half the length of the spinithrix or less. As with bifid spinitriches, the prongs of trifid forms can be parallel to one another (e.g., Figs. 6F, I, L), they can converge upon one another, or they can diverge from one another (e.g., Figs. 6K, M). The prongs can be equal to one another in width (e.g., Figs. 6E, H), or they can be of unequal widths (e.g., Figs. 6J, K). In some cases the prongs are of equal lengths (e.g., Figs. 6I, L); in others they are of unequal lengths (e.g., Figs. 6G, J). Trifid spinitriches have been observed in a diversity of trypanorhynchs (e.g., Palm 2004).

(xiii) Trifurcate (divided into three long parts)

(trifurcus; L., three-forked) Figs. 2, 6N, O

The three prongs of trifurcate spinitriches are long, comprising much of the length of the spinithrix. This form is relatively rare, having been observed to date only in diphyllideans (e.g., Tyler 2006). The slender, elongate prongs of these spinitriches are easily mistaken for capilliform filitriches in instances in which they are closely packed and the basal point of confluence of the prongs is not visible. In some cases, the elongate prongs conspicuously differ in width (e.g., Fig. 6O), in others they are more similar in width (e.g., Fig. $6 \mathrm{~N}$ ).

\section{B. Spinitriches in which width and thickness are approximately equal \\ Figs. 2, 7-9}

(xiv) Chelate (pincer-like) (chela; L., claw) Figs. 2, 7L

These spinitriches are relatively elongate and round in cross-section; they terminate in a pair of pincer-like digits. They have been likened to the pedicellariae of echinoderms (e.g., Carvajal et al. 1987). To date, this form of spinithrix has been observed, for example, on the margins of the bothria of trypanorhynchs of the family Lacistorhynchidae (e.g., Richmond and Caira 1991, Palm 2004).

(xv) Clavate (club-shaped) (clava; L., club)

Fig. 2

Clavate spinitriches are round in cross-section, but narrower distally than proximally, and they also possess a constriction at about their midlevel. Thus, they resemble bowling pins or clubs in form. This is among the more unusual spinithrix types. This form may occur in haplobothriideans (e.g., MacKinnon and Burt 1985b, fig. 8). However, to date it is known only from TEM images and it is possible that the shape is an artifact of the plane of sectioning. Nonetheless, this term is appropriate for spinitriches of this form should they be verified to exist.

(xvi) Columnar (column-like in shape) (columna; L., pillar)

Figs. 2, 7M

These spinitriches are round in cross-section, but possess sides that are parallel to one another throughout most of the length of the spinithrix. However, they generally taper distally to a rounded or, in some instances, relatively pointed end. This form of spinithrix is among those seen, for example, in litobothriideans (e.g., Olson and Caira 2001).

(xvii) Coniform (shaped like a cone) (conus; L., cone) Figs. 2, 3M, 7G-K, 9A-D

This form is round in cross-section, possesses straight sides, but, unlike the columnar form, tapers gradually throughout most of its length to a fine point. This form has been observed on the scolices of some trypanorhynchs (e.g., Palm 2004), litobothriideans (e.g., Olson and Caira 2001), lecanicephalideans (e.g., Jensen 2005), and on the cirrus of some tetraphyllideans (e.g., Figs. 9C, D) and cyclophyllideans (e.g., Fig. 9B). In the rare cases in which two coniform spinitriches arise from a single base (e.g., Fig. $7 \mathrm{~K}$ ), the term duplicated may be used prior to all other spinithrix modifiers.

(xviii) Costate (bearing longitudinal ridges) (costatus; L., ridged, ribbed)

Fig. 2

Such spinitriches have ridges that extend parallel to their long axis. The ridges can be confined to the base or extend throughout the length. There may be a single ridge, as for example seen in the tetrathyridium of Mesocestoides Vaillant, 1863 by Hess and Guggenheim (1977), or multiple ridges (or "flanges") may be present, as for example was reported in the cysticercoid of Ophryocotyle Friis, 1870 by MacKinnon and Burt (1983). The ridging seen in costate spinitriches is not to be confused with the occurrence of the more delicate surface ribbing seen on some palmate spinitriches (e.g., Figs. 6T, U).

(xix) Cyrillionate (resembling a jug with a narrow neck) (kyrillion; G., a jug with a narrow neck) Figs. 2, 7P

These small spinitriches are ovate basally but taper relatively abruptly to a point. The junction between the ovate base and the tapering distal region is relatively abrupt, rather than gradual. These spinitriches appear to be rare. To date they are known from tetraphyllidean genera such as Nandocestus Reyda, 2008 (e.g., Reyda 2008).

(xx) Hastate (having the shape of an arrowhead) (hasta; L., spear-shaped, arrow-shaped)

Figs. 2, 7R-T

These spinitriches are triangular in overall form, and may possess conspicuous basal lobes or shoulders on either side (e.g., Fig. 7T). Hastate spinitriches are perhaps 


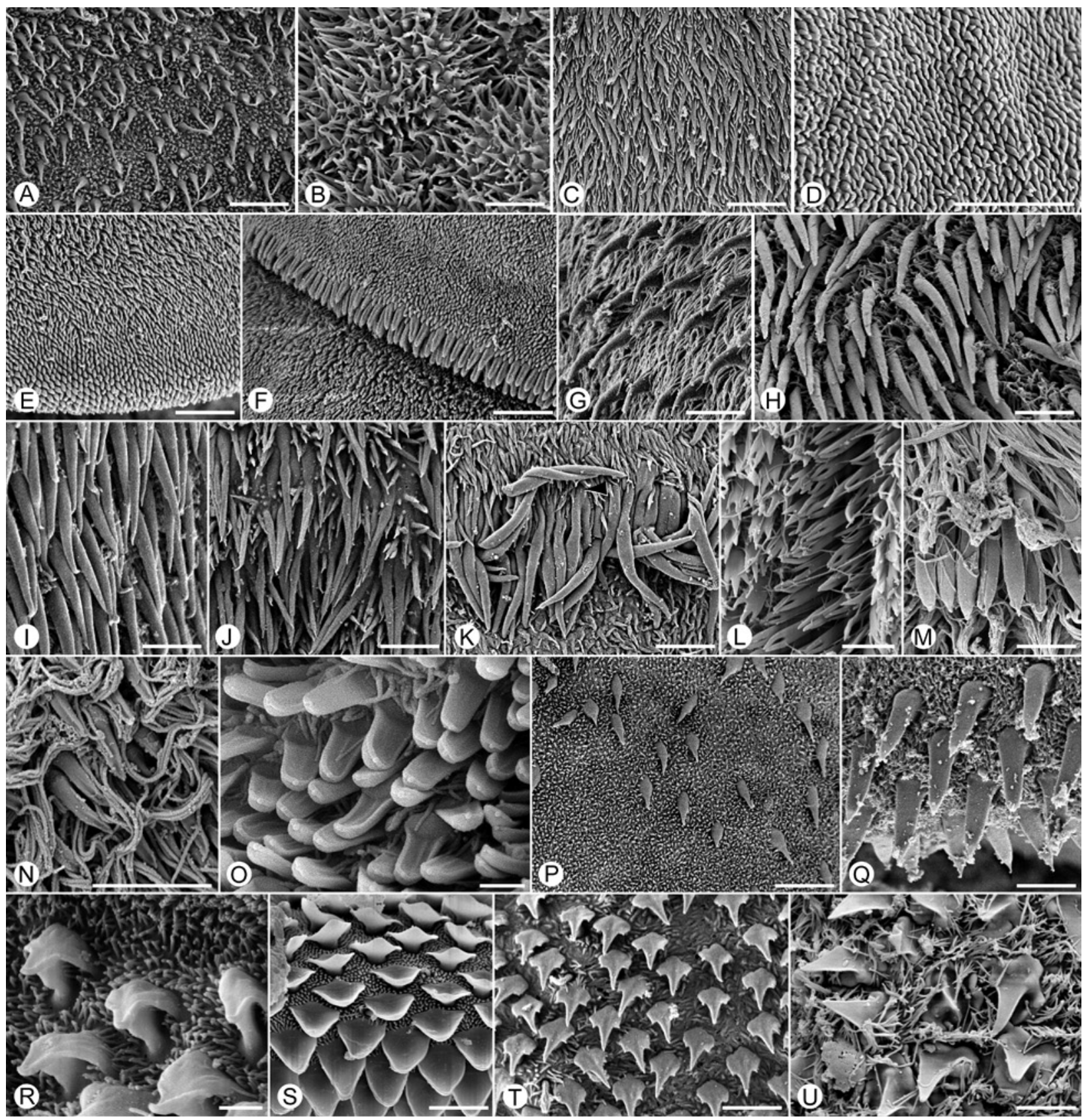

Fig. 7. Scanning electron micrographs illustrating some spinithrix forms in which width and thickness are approximately equal. A - Distal bothridial surface of Scalithrium sp.; scolopate spinitriches and papilliform filitriches. B - Distal bothridial surface of Anthocephalum alicae; scolopate spinitriches. C - Stalk of Anthocephalum centrourum; scolopate spinitriches and acicular filitriches. D - Anterior strobila of Cephalobothrium sp.; scolopate spinitriches. E - Posterior margin of proglottid of Aberrapex senticosus; scolopate spinitriches (of slightly different sizes). F - Posterior margin of proglottid of Polypocephalus sp.; scolopate and trullate spinitriches. $\mathbf{G}$ - Distal sucker surface of Cephalobothrium sp.; coniform spinitriches and acicular filitriches. $\mathbf{H}$ - Scolex proper between bothria of Heteronybelinia estigmena; coniform spinitriches and capilliform filitriches. I - Apex of scolex of "mushroom" type new litobothriidean; coniform spinitriches. J - Proglottid of "mushroom" type new litobothriidean; aristate coniform spinitriches and papilliform filitriches. K - Proglottid of "mushroom" type new litobothriidean; duplicated aristate coniform spinitriches (arrowhead) and acicular filitriches. $\mathbf{L}$ - Bothrial rim of Callitetrarhynchus gracilis; chelate spinitriches, trifid spinitriches and capilliform filitriches. $\mathbf{M}$ - Posterior margin of first pseudosegment in Litobothrium daileyi; columnar spinitriches and capilliform filitriches. $\mathbf{N}$ - Rim of sucker of Lecanicephalum sp.; trullate spinitriches and capilliform filitriches. O - Distal bothridial surface of Crossobothrium sp.; trullate spinitriches and acicular filitriches. P - Proximal bothridial surface near bothridial rim of Nandocestus guariticus; cyrillionate spinitriches and papilliform filitriches. $\mathbf{Q}$ - Rim of sucker of Quadcuspibothrium francisi; rostrate spinitriches and acicular filitriches. $\mathbf{R}$ - Apical modification of scolex proper of new genus of lecanicephalidean; hastate spinitriches and acicular filitriches. S - Sucker margin of Aberrapex manjajae; hastate spinitriches and papilliform filitriches. T - Apical modification of scolex proper of Polypocephalus helmuti; hastate spinitriches and acicular filitriches. $\mathbf{U}$ - Rim of sucker of new lecanicephalidean from Narcine lingula; rostrate spinitriches and capilliform filitriches. Scale bars: Figs. A-N, P, Q, S-U $=2 \mu \mathrm{m}$; Figs. O, R $=1 \mu \mathrm{m}$. 
most easily confused with gladiate spinitriches in instances in which their full thickness (e.g., Fig. 7R) is not visible, or is difficult to observe. This type of spinithrix has been observed on the scolex of cyclophyllidean (Davaineidae) genera such as Raillietina Fuhrmann, 1920 and Cotugnia Diamare, 1893 (e.g., Bâ et al. 1995) and in a diversity of lecanicephalideans (e.g., Jensen 2005).

(xxi) Rostrate (beak-like) (rostratus; L., beaked, curved)

Figs. 2, 7Q, U, 9E-G

These spinitriches are abruptly reflexed proximally, which gives them a beak-like appearance. In some instances they bear a complex base (e.g., Figs. 7U, 9F), in others the bases may be simple (e.g., Figs. 7Q, 9E, G). Rostrate spinitriches have been observed in some lecanicephalideans (e.g., Jensen 2001). They have also been observed on the cirrus of some tetraphyllideans (e.g., Reyda 2008).

(xxii) Scolopate (thorn-like) (skolops; G., pointed object, thorn) Figs. 2, 7A-F

These are among the smallest spinithrix forms. They possess either straight or slightly convex sides and taper gradually distally. They have been observed in several rhinebothriideans (e.g., Healy 2006a, b) and are relatively common in lecanicephalideans (e.g., Jensen 2005).

(xxiii) Stellate (star-shaped) (stella; L., star) Figs. 2, 9J

These spinitriches bear multiple prongs aggregated into a star-like cluster. We believe the structures reported on the cirrus of Euzetiella tetraphylliformis de Chambrier, Rego et Vaucher, 1999 by de Chambrier et al. (1999) (Fig. 9J) are of this form. It should be noted that we do not consider spinitriches such as those seen on the cirrus of Nandocestus (e.g., Reyda 2008, Fig. 9F) to be stellate; despite the somewhat stellate form of the base, these spinitriches bear only a single structure radiating from this base.

(xxiv) Trullate (shaped like a dipper or scoop) (trulla; L., dipper, scoop)

Figs. 2, 7F, N, O

These spinitriches bear a concavity on their dorsal surface and thus resemble a dipper or scoop. The concavity may be restricted to a portion of their length (e.g., Fig. $7 \mathrm{~N}$ ), or it may extend throughout their length (e.g., Fig. 7O). They have been observed to date in bothriocephalideans such as Paraechinophallus Protasova, 1979 (e.g., the "tusk-like" spinitriches described by Levron et. al. 2008a), in some lecanicephalideans (e.g., Jensen 2005), and in tetraphyllideans such as Crossobothrium (Ivanov pers. comm.).

(xxv) Uncinate (hook-shaped) (uncinatus; L., hooked)

Figs. 2, $9 \mathrm{H}$

Unlike hamulate spinitriches, these hook-shaped spinitriches are not laterally flattened, rather they have a substantial width (and also thickness) to them. These spinitriches usually conspicuously curve posteriorly. They have been observed on the cirrus of some tetraphyllideans (e.g., Fig. 9H) (Caira unpubl.).

\section{Marginal and/or dorsoventral modifications}

As noted above, in the terminology described here, marginal and/or dorsoventral modifications are considered independently of spinithrix shape. This is because it appears possible for spinitriches of a variety of different forms to exhibit apical and marginal and/or dorsoventral modifications. Thus, while many spinitriches are entirely smooth, a number of spinithrix forms bearing projections have also been observed. Such projections can be restricted to the lateral margins, or to the dorsal surface, or they can be found on all surfaces of the spinithrix. They can occur throughout the length of the spinithrix, or they can be restricted to only a portion of the length of the spinithrix. The projections are narrow, but can vary somewhat in length.

We have attempted to simplify the terminology used to describe marginal and dorsoventral spinithrix projections by recognising only two nominal categories of such modifications: serrate and gongylate. In the former case, the projections are restricted to the margins of the spinithrix; in the latter case they are more extensively distributed, occurring somewhere on the dorsal and/or ventral surfaces. We believe that this scheme will accommodate at least all of the variation seen to date, and hopefully is sufficiently flexible to also accommodate at least some of the potential variation not yet observed.

Serrate (with forward-projecting teeth) (serra; L., saw)

Figs. 2, 3L, 5A-I

Serrate spinitriches are those that bear marginal projections. In all cases these projections are forward pointing; they can vary in length; long projections are seen in some taxa (e.g., Figs. 5D, I), and shorter projections exist in others (e.g., Figs. 5C, E). The projections can be evenly spaced along the margins (e.g., Figs. 5E, F, H, I), or they can be more irregularly spaced (e.g., Figs. 5A-C). In some cases, the marginal projections occur along the entire length (e.g., Figs. 5H, I); in other cases they appear to be restricted to a portion of the distal half of the spinithrix (e.g., Fig. 5C). In rare instances, spinitriches bearing what appear to be both a dorsal and ventral band of marginal projections have been seen (e.g., Fig. 3L). We recommend that such variation in length and spacing of the projections be noted. However, we have not developed specific terminology to accommodate such variation. Spinitriches in which all of the projections are restricted to the distal lateral margins should be considered palmate, rather than serrate.

Serrate spinitriches have been reported from tetraphyllidean cestodes, most commonly from the tetraphyllidean genera Paraorygmatobothrium (e.g., Ruhnke and Carpenter 2008) and Orectolobicestus (e.g., Ruhnke et al. 


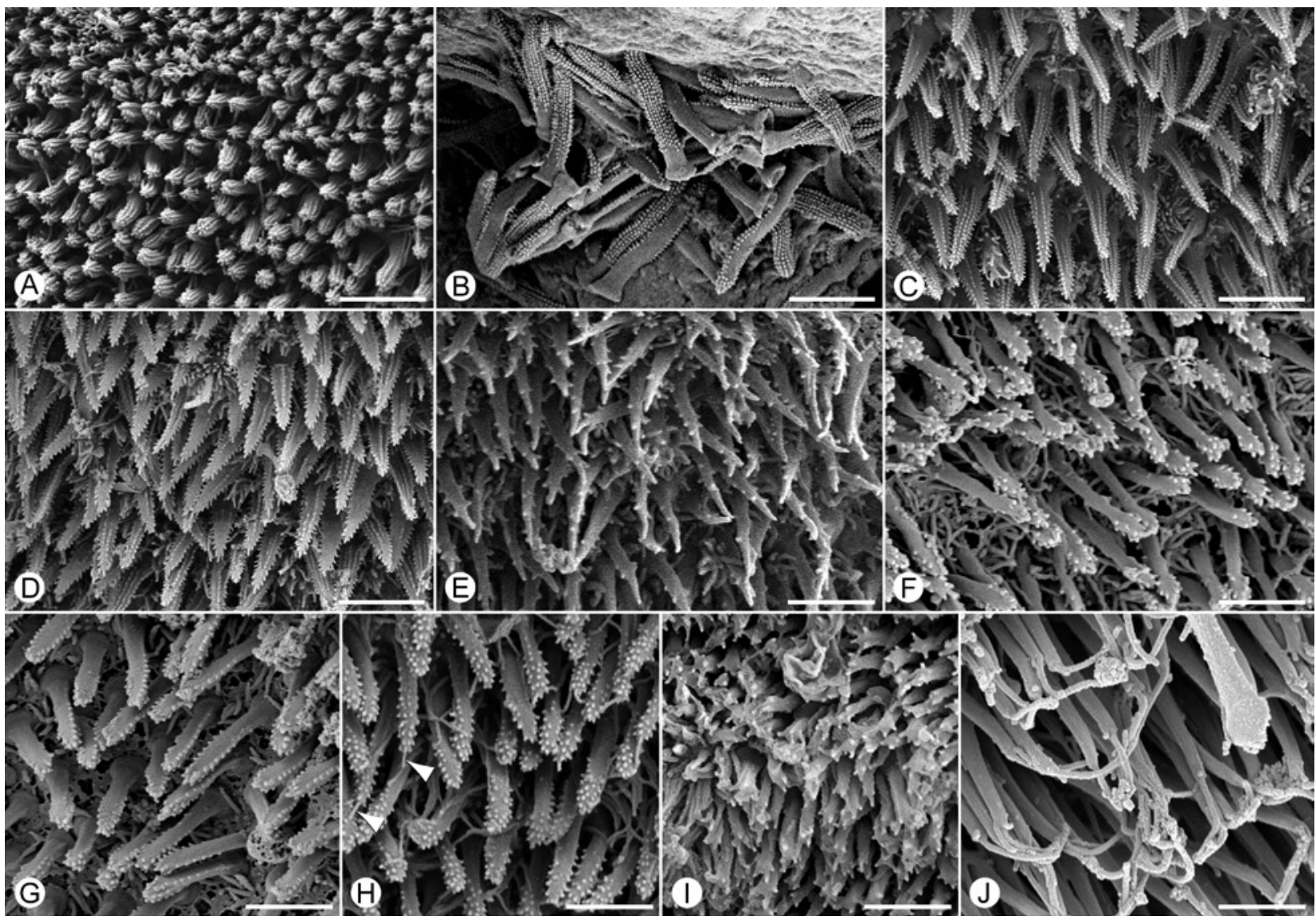

Fig. 8. Scanning electron micrographs illustrating dorsoventral modifications of some spinithrix forms in which width and thickness are approximately equal. A - Distal bothridial surface of Phyllobothrium squali; gongylate columnar spinitriches and capillate filitriches. B - Distal bothridial surface of Pithophorus sp.; gongylate columnar spinitriches (projections restricted to distal surface). C - Distal surface of Paraorygmatobothrium sp.; gongylate coniform spinitriches and acicular filitriches. D - Distal surface of Paraorygmatobothrium sp.; gongylate coniform spinitriches and acicular filitriches. E - Distal bothridial surface of Anthocephalum sp.; gongylate coniform spinitriches and acicular filitriches. F - Distal bothridial surface of Orectolobicestus kelleyae; gongylate columnar spinitriches (projections restricted to distal tips) and capilliform filitriches. G - Distal surface of marginal loculus on bothridium of Orectolobicestus mukahensis; gongylate columnar spinitriches and acicular filitriches. H - Distal bothridial surface of Orectolobicestus lorettae; mixture of gongylate columnar spinitriches and aristate gongylate columnar spinitriches (white arrowheads) and capilliform filitriches. I - Distal bothridial surface of Clistobothrium montaukensis; gongylate columnar spinitriches (projections restricted to distal tips; projections somewhat longer than typically seen). J - Distal surface of bothridial apical sucker of Marsupiobothrium sp.; columnar spinitriches with three terminal projections of unequal length. Scale bars: Figs. A-D $=2 \mu \mathrm{m}$; Figs. E $-\mathrm{J}=1 \mu \mathrm{m}$.

2006a). They have also been observed in trypanorhynch genera such as Grillotia Guiart, 1927 (e.g., Palm 2004).

Gongylate (bearing multiple small projections)

(gongylos; G., ball, round, spherical) Figs. 2, 8A-H

Gongylate spinitriches bear at least some projections on their dorsal and/or ventral surfaces. The projections can be small and ball-like (e.g., Fig. 8B), or more elongate, approaching the length of those seen on serrate spinitriches (e.g., Figs. 8C, D). Substantial variation is seen in the distribution of the projections. In many cases, the projections occur on both the dorsal and ventral surfaces (e.g., Figs. 8A, C, D); in rarer cases they are restricted to one side, normally the dorsal surface (e.g., Fig. 8B). The projections can occur throughout the length (e.g., Fig.
$8 \mathrm{C})$ or they can be restricted to, or at least concentrated at, the distal tip (e.g., Fig. 8F). The projections are often arranged in regular columns (Figs. 8A, C, D). However, they can also be arranged relatively irregularly (e.g., Fig. $8 \mathrm{~F}$ ), and in a number of cases they are concentrated on the margins (e.g., Figs. 8E, G). It was the column-like arrangement of projections that led authors to refer to this form as "ear-of-corn" (Whittaker and Carvajal 1980), and "maiziform" (e.g., Caira et al. 1999). We recommend that such variation in the arrangement of projections on gongylate spinitriches be noted, but again, we have refrained from developing a more specific terminology to describe this variation at this time.

Gongylate spinitriches have been observed in tetraphyllidean cestodes, most commonly those of the gen- 
era Paraorygmatobothrium (e.g., Ruhnke and Carpenter 2008), Orygmatobothrium (e.g., Ivanov 2008), and Orectolobicestus (e.g., Ruhnke et al. 2006a).

It appears that several variations on the gongylate spinithrix theme may occur in at least some tetraphyllidean taxa. For example, Clistobothrium Dailey et Vogelbein, 1990 appears to possess spinitriches that bear a ring of projections around the margin of their distal surface (Fig. 8I). However, little is known of this form and available images suggest that these structures might actually represent a fusion of multiple capilliform filitriches (Caira, pers. obs.). In addition, spinitriches bearing multiple terminal projections of markedly unequal length (e.g., Fig. 8J) have been observed in other tetraphyllideans. Again, at present it is not clear how this form should be interpreted. Additional data are required before it can be fully categorised.

\section{Apical modifications}

Aristate (having a bristle-like tip) (arista; L., bristle)

Figs. 5J-O

Aristate spinitriches bear a bristle-like tip. Some variation in the length of this projection occurs. In some species it is relatively short (e.g., Figs. 5J, O), in others it is relatively long (e.g., Figs. 5K, L), in yet others it is conspicuously long, sometimes approaching the length of the spinithrix proper (e.g., Figs. 5M, N). We recommend that apical projections be noted when observed. It appears that a diversity of spinithrix forms can bear an apical projection. For example, aristate gladiate spinitriches (e.g., Figs. 5J, K, M, N), aristate lingulate spinitriches (Fig. 5L), aristate spathulate spinitriches (e.g., Fig. 5P) and aristate lanceolate spinitriches (e.g., Fig. 5O) are known to exist. Aristate coniform spinitriches have also been observed (e.g., Fig. 7J).

Aristate modifications of spinitriches have been observed, for example, in tetraphyllidean genera such as Pedibothrium Linton, 1908 (e.g., Caira 1992, Caira et al. 2004), Yorkeria (e.g., Caira and Tracy 2002), Anthobothrium van Beneden, 1850 (e.g., Ruhnke and Caira 2009), and also in litobothriideans (e.g., Olson and Caira 2001), and tetrabothriideans (Fig. 5O).

\section{SUMMARY OF TERMINOLOGY}

Fig. 2 was designed to summarise, and thereby facilitate application of, the terms proposed above for filitriches and spinitriches. For the sake of consistency, we recommend that the proposed modifiers precede the term spinithrix or filithrix in the sequence shown in Fig. 2. Schematic representations are also provided to illustrate some of the combinations of terms that can, for example, be applied to a particular length (e.g., acicular) of filithrix, and to two particular shapes of spinitriches (i.e., gladiate and columnar).
Filitriches ( $\leq 200 \mathrm{~nm}$ in basal width)

Fig. 2

Given that variation in filitriches generally involves only length, most filitriches will require only one modifier in a sequence, i.e., the length modifier. Thus, collectively, the terms papilliform filithrix, acicular filithrix, and capilliform filithrix capture most of the diversity seen in filitriches. Only a single length modifier should be applied to any particular filithrix. In the few instances in which two of these structures arise from a single base, an additional modifier is required. In the case of such duplications, the additional modifier "duplicated" should precede the length modifier. Given the rarity of the duplicated condition, the use of a specific term for the single condition is not advocated.

\section{Spinitriches ( $>200 \mathrm{~nm}$ in basal width)}

Fig. 2

Variation seen in spinitriches requires a more complex terminology. As many as three modifiers in sequence may be required to fully describe some spinithrix morphologies. Once again, for the sake of consistency, we recommend that these modifiers precede the term spinithrix in the specific sequence shown from left to right in Fig. 2. The shape modifier immediately precedes the term spinithrix. At this point we recognise 25 different spinithrix forms; 13 of these describe variations in spinitriches that are wider than they are thick, and 12 of these describe variations in spinitriches that are approximately as wide as they are thick. Only a single shape modifier should be applied to any particular spinithrix; descriptions of all spinitriches should be accompanied by one of these shape modifiers. The marginal and/or dorsoventral modifier precedes the shape modifier in sequence, but only in the cases of spinitriches that exhibit such modifications. To date, only two options for the marginal and/or dorsoventral modifier have been articulated (i.e., serrate and gongylate). In the absence of a marginal and/or dorsoventral modifier, a spinithrix should be assumed to lack such projections (i.e., the use of a specific term for spinitriches that lack such projections is not advocated). The apical modifier precedes the marginal and/or dorsoventral modifier (if present) in sequence, but only in the cases of spinitriches that exhibit an apical modification. To date the only apical modification observed is the presence of a bristle-like (i.e., aristate) tip. Once again, in the absence of the apical modifier, a spinithrix is assumed to lack an apical modification (i.e., the use of a specific term for spinitriches lacking an aristate tip is not advocated).

\section{FUTURE CONSIDERATIONS}

Given the relatively broad suite of taxa that has been examined for microthrix variation, a pattern has begun to emerge indicating likely avenues to pursue for the discovery of additional microthrix variation. With respect to filitriches, acicular and capilliform filitriches appear to be 


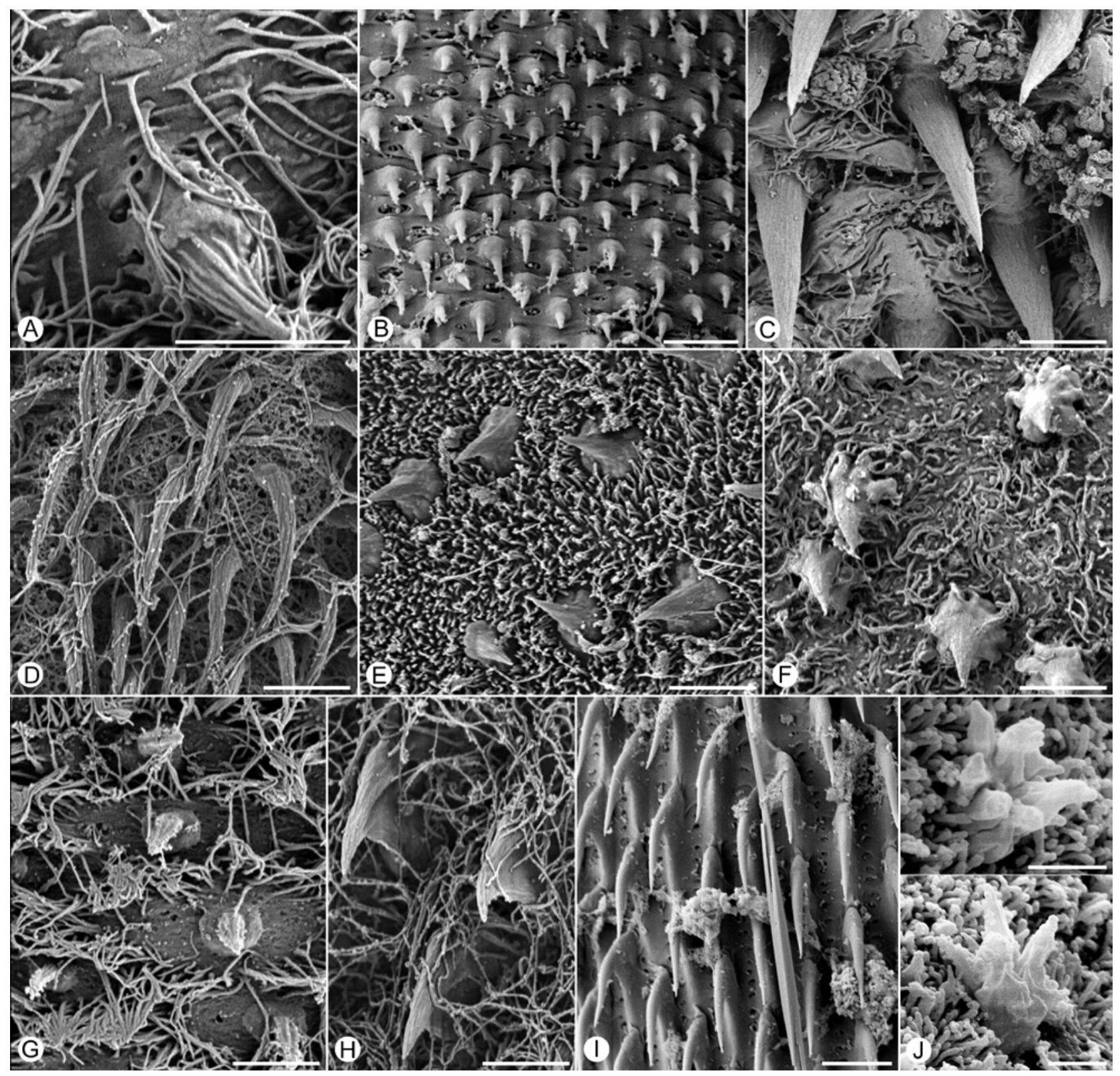

Fig. 9. Scanning electron micrographs illustrating cirrus microtriches. A-Cirrus of Rhinebothrium sp.; coniform spinithrix and capilliform filitriches with unusual bases. B - Distal region of cirrus of Progynotaenia odhneri; coniform spinitriches. C - Cirrus of Rhinebothrium sp.; coniform spinitriches and capilliform filitriches. D - Cirrus of new genus of tetraphyllidean from Pristis clavata; coniform spinitriches and capilliform filitriches. $\mathbf{E}$ - Cirrus of new genus of tetraphyllidean from Pristis clavata; rostrate spinitriches and capilliform filitriches. F - Cirrus of Nandocestus guariticus; rostrate spinitriches (with stellate bases) and capilliform fillitriches. $\mathbf{G}$ - Cirrus of Rhinebothrium copianullum; rostrate spinitriches and capilliform filitriches. $\mathbf{H}$ - Cirrus of new genus of tetraphyllidean from Pristis clavata; uncinate spinitriches and capilliform filitriches. I - Proximal region of cirrus of Progynotaenia odhneri; hamulate spinitriches. J - Cirrus of Euzetiella tetraphylliformis; stellate spinitriches and acicular filitriches (shown two slightly different views). Scale bars: Figs. A-H, J $=2 \mu \mathrm{m}$; Fig. I $=4 \mu \mathrm{m}$.

widely distributed, and perhaps even ubiquitous, among the tapeworm orders. Papilliform filitriches appear to be more restricted taxonomically. We predict that little additional variation will be found in filithrix form.

The situation with spinitriches is likely to be quite different. Gladiate and coniform spinitriches, of a variety of widths and sizes, are by far the most commonly seen spinithrix shapes, each having been observed in members of most orders of tapeworms. This is not the case for the other spinithrix shapes. In fact, most of the other 23 spinithrix shapes, and also spinitriches with marginal and/or dorsoventral and apical modifications, have been reported solely from the elasmobranch-parasitizing orders Trypanorhyncha, Diphyllidea, Lecanicephalidea, 
Tetraphyllidea, and Rhinebothriidea. Since these groups are in need of further study, they are likely to continue to be productive avenues of spinithrix investigation. As data on these taxa continue to be compiled, it seems likely that spinithrix forms may be found to represent useful synapomorphies for subsets of these taxa. In addition, preliminary data available on cyclophyllidean families other than the Taeniidae (e.g., the Hymenolepididae, Anoplocephalidae, Davaineidae, etc.) have revealed a diversity of interesting spinithrix forms (e.g., Bâ et al. 1995). Furthermore, the fact that at least some of the rostellar elements of these and other taxa, which have up to now been interpreted as hooks, hooklets, or spines, may be determined to be large microtriches (e.g., Mount 1970, Thompson et al. 1980, Biserova 1991, Stoitsova et al. 2001), provides a number of intriguing avenues for investigation. This is likely also true for at least some of the structures associated with the rostellum of some proteocephalideans (Scholz et al. 1999).

Examination of the surface of the cirrus and lining of the vagina of a diversity of tapeworms suggests that these organs are also worthy of further attention, particularly in the cestode orders in which they have not been explored in much detail to date. We have presented exemplar images of microtriches from cirrus surfaces (Fig. 9) separately from images of microtriches found on the various surfaces of the scolex and strobila (Figs. 3-8) in an attempt to illustrate some of the trends that appear to be emerging with respect to cirrus microtriches. For example, unlike most other regions of the body, it is not uncommon to find cirri bearing spinitriches, but lacking filitriches (e.g., Figs. 9B, I). There appears to be much less variation in the form of cirrus microtriches than seen among microtriches elsewhere on the body; those of the cirrus tend to be coniform, uncinate, or rostrate. However, the extent to which these observations can be generalised across cestode taxa requires substantial additional work, as do generalisations regarding the form of vaginal microtriches. We predict that additional work on the surfaces of these reproductive structures across a diversity of taxa will yield additional forms. It is also likely that progress will be greatly facilitated by the use of a combination of SEM and TEM methods. For example, the recent work of Poddubnaya and Mackiewicz (2009) provided some interesting interpretations of the surface features on the cirri of two species of echinophallids (Bothriocephalidea).

Although several studies have addressed the processes by which microtriches are formed, our understanding of the development of these structures remains far from complete. In general, the tegument of cestode larvae (i.e., the hexacanth sensu Conn and Świderski 2008) bears microvilli, while that of metacestodes (sensu Chervy 2002) and adults bears microtriches (see Conn 2004, Conn and Świderski 2008). However, several scenarios have been described with respect to the actual formation of microtriches. The primary distinction among scenarios appears to be whether microtriches are formed de novo, or via the conversion of microvilli by the addition of electron-dense material to form the cap (e.g., Hulínská 1980, MacKinnon and Burt 1984). Two scenarios of formation de novo have been described. Either the microthrix forms below the plasmalemma and is erected (e.g., Timofeev and Kuperman 1972, Lumsden et al. 1974, Hess 1980), or electrondense material is added beneath the plasmalemma followed by formation of the base (e.g., Richards and Arme 1984). In some cases, both of these modes of de novo formation have been reported in the same taxon (e.g., Rogan and Richards 1987). There even exist reports of both the transformation of microvilli into microtriches and the de novo formation of microtriches in the same stage of the same species (e.g., Davydov et al. 1995). It remains to be determined if the differences observed can be attributed to differences among taxa, developmental stages, or sites within a species. However, it is interesting that different processes have been reported within the same developmental stage of the same species (e.g., Ubelaker 1980, Richards and Arme 1984). Clearly, much work remains to be done in this area. Furthermore, Biserova (1991) actually considered the hooks of the rostellum and peduncle of diphyllideans to be homologous with the microtriches she recognised as "polymicrotriches".

Finally, while the potential functions of microtriches have been discussed on numerous occasions (e.g., Threadgold 1962, Rothman 1963, Morseth, 1966, McVicar 1972, Lumsden, 1975b, Lumsden and Murphy 1980, Thompson et al. 1980, Lumsden and Hildreth 1983, Coil 1991, Hayunga 1991), in fact, much remains to be learned of the roles microtriches actually play in the lives of cestodes. Among the functions attributed to microtriches are: absorption of nutrients, amplification of the absorptive surface area, attachment to the surface of the host intestinal tract either to aid in movement, or to prevent expulsion, agitation of their microhabitat, abrasion of the mucosal surface so as to increase the concentration of nutrients adjacent to the worm, warding off of host cells, and maintaining a barrier between the tegument and the mucosal surface. However, at least some of these roles have never been definitively documented. Evidence also exists that microtriches play an integral role in the formation of certain "hard" structures in cestodes. For example, Mount (1970) provided convincing evidence that the rostellar hooks of Taenia crassiceps (Zeder, 1800) originate through the enlargement of spinitriches. However, the processes by which hooks are formed in most other cestode groups remain completely unknown. Also, given the diversity of cestode epithelial structures described to date (see Jones 1998), it would be interesting to know if microtriches play a role in the function of any of these other structures.

All data to date suggest that microtriches are restricted to members of the class Cestoda. Reports of these structures from species belonging to other invertebrate taxa appear to be unjustified. For example, the acanthocephalan 
surface features identified as microtriches by Amin et al. (2009) lack the key features of microtriches as articulated here and thus should be discounted as erroneous reports.

Acknowledgements. The microthrix terminology proposed here is the result of group discussions that began at the 4th International Workshop on Cestode Systematics in Storrs, Connecticut, USA in 2002, continued at the 5th International Workshop on Cestode Systematics and Phylogeny in České Budějovice, Czech Republic in 2005, and concluded at the 6th International Workshop on Cestode Systematics in Smolenice, Slovakia in 2008. The following individuals, listed in alphabetical order, contributed to the ultimate formalisation of this microthrix terminology through their participation in discussions at one or more of these three workshops: Cheike Tidiane Bâ, Ian Beveridge, Natalia Biserova, Rod Bray, Mick Burt, Janine Caira, Juan Carvajal, Alain de Chambrier, Bruce Conn, Louis Euzet, Carrie Fyler, Boyko Georgiev, David Gibson, Claire Healy, Vladimíra Hanzelová, Veronica Ivanov, Lena Jarecka, Kirsten Jensen, Arlene Jones, Vadim Kornyushin, Roman Kuchta, the late Boris Kuperman, Céline Levron, Jean Mariaux, Fernando Marques, Pavel Nikolov, Peter Olson, Mikuláš Oros, Harry Palm, Maria Pickering, Larisa Poddubnaya, Amilcar Rego, Florian Reyda, Tim Ruhnke,
Tomáš Scholz, Piotr Świderski, Gaines Tyler, and Gergana Vasileva. Comments provided by John Oaks and John Mackiewicz did much to improve an earlier version of the manuscript. Helpful input on an earlier version of this manuscript also came from I. Beveridge, C. Healy, V. Ivanov, K. Jensen, R. Kuchta, C. Levron, Tim Littlewood, Masoumeh Malek, H. Palm, L. Poddubnaya, and T. Scholz. The electron micrographs presented were provided by J. Caira (Figs. 3A-C, F, I, K, O, P; 4A, B, J-R, T, U; 5A-C, E-G, J, K, M, N, P; 6B, C, E, G, H, L, P, b; 7H-K, M; 8A, C, D, F-I; 9D-F, H), A. de Chambrier (Fig. 9J), C. Fyler (Fig. 1), C. Healy (Figs. 3D, E, N; 5D, H, I; 6A, Q, Y; 7A-D, G; 8B, E, J), V. Ivanov (Figs. 4S, 5O, 7O), K. Jensen (Figs. 3G, M; 4C-E, G-I, L; 6D, F, I-K, T, U; 7E, F, L, N, Q, R, U; 9B, I), C. Levron (Figs. 3H, J; 4F), F. Reyda (Figs. 7P; 9A, C, F, G), and G. Tyler (Figs. 3L, 6M-O, R, S, V-X, Z, a). The extensive review of the literature that is central to this paper would not have been possible without the able assistance of Elizabeth Barbeau. $\mathrm{K}$. Jensen provided invaluable assistance with the compilation and presentation of all of the figures presented here. R. Kuchta's attention to detail is also greatly appreciated. This work was supported in part with funds from the National Science Foundation DEB Nos. 0818696 and 0818823 and the Grant Agency of the Czech Republic (Project No. 524/07/P039).

\section{REFERENCES}

Agustí C., Aznar F.J., Raga J.A. 2005: Microtriches of tetraphyllidean metacestodes from Western Mediterranean striped dolphins (Stenella coeruleoalba). J. Morphol. 265: 176-189.

Amin O., Heckmann A., Radwan N.A.E., Mantuano Anchundia J.S., Zambrano Alcivar M.A. 2009: Redescription of Rhadinorhynchus ornatus (Acanthocephala: Rhadinorhynchidae) from skipmack tuna, Katsuwonus pelamis, collected in the Pacific Ocean off South America, with special reference to new morphological features. J. Parasitol. 95: 656-664.

Andersen K.I. 1975: The functional morphology of the scolex of Diphyllobothrium Cobbold (Cestoda, Pseudophyllidea), a scanning electron and light microscopical study on scoleces of adult D. dendriticum (Nitzsch), D. latum (L.) and D. ditremum (Creplin). Int. J. Parasitol. 5: 487-493.

Andersen K.I. 1979: Studies on the scolex morphology of Eubothrium spp. with emphasis on characters usable in species discrimination and with brief references on the scolices of Bothriocephalus sp. and Triaenophorus spp. (Cestoda; Pseudophyllidea). Z. Parasitenkd. 60: 147-156.

Andersen K.I. 1987: S.E.M. observations on plerocercus larvae of Floriceps saccatus Cuvier, 1817 and Molicola horridus (Goodsir, 1814) (Cestoda; Trypanorhyncha) from sunfish (Mola mola). Fauna Norv., Ser. A, 8: 25-28.

Andersen K.I., Gibson D.I. 1989: A key to three species of larval Diphyllobothrium Cobbold, 1858 (Cestoda: Pseudophyllidea) occurring in European and North American freshwater fishes. Syst. Parasitol. 13: 3-9.

Andersen K.I., LysfJord S. 1982: The functional morphology of the scolex of two Tetrabothrius Rudolphi 1819 species (Cestoda; Tetrabothriidae) from penguins. Z. Parasitenkd. 67: 299-307.

Anonymous 1962: Report of the Systematics Association Committee for Descriptive Biological Terminology, II and IIa. Terminology of simple symmetrical plane shapes (Charts 1, 1a). Taxon 11: 145-155, 245-247.

Arrendondo N.J., Gil de Pertierra A.A. 2008: The taxonomic status of Spatulifer cf. maringaensis Pavanelli \& Rego, 1989
(Eucestoda: Proteocephalidea) from Sorubim lima (Bloch \& Schneider) (Pisces: Siluriformes), and the use of microthrix pattern in the discrimination of Spatulifer spp. Syst. Parasitol. 70: 223-236.

Ashour A.A., Koura E.A., Wanas M.Q. 1994: Ultrastructural study of the body surface and the flame cell of Oochoristica sp. (Cestoda: Anoplocephalidae). J. Egypt. Soc. Parasitol. 24: 295-303.

BÂ C.T., SÉne T., Marchand B. 1995: Scanning electron microscope examination of scale-like spines on the rostellum of five Davaineinae (Cestoda, Cyclophyllidea). Parasite 2: 63-67.

BARON P.J. 1968: On the histology and ultrastructure of Cysticercus longicollis, the cysticercus of Taenia crassiceps Zeder, 1800, (Cestoda, Cyclophyllidea). Parasitology 58: 497-513.

BARON P.J. 1971: On the histology, histochemistry and ultrastructure of the cysticercoid of Raillietina cesticillus (Molin, 1858) Fuhrmann, 1920 (Cestoda, Cyclophyllidea). Parasitology 62: 233-245.

BÉGUIN F. 1966: Étude au microscope electronique de la cuticle et de ses structures associées chez quelques cestodes. Essai d'histologie comparée. Z. Zellforsch. 72: 30-46.

Berger J., Mettrick D.F. 1971: Microtrichial polymorphism among hymenolepid tapeworms as seen by scanning electron microscopy. Trans. Am. Microsc. Soc. 90: 393-403.

Beveridge I., Campbell R.A. 2001: Grillotia australis n. sp. and G. pristiophori n. sp. (Cestoda: Trypanorhyncha) from Australian elasmobranch and teleost fishes. Syst. Parasitol. 49: 113-126.

Beveridge I., Jones M.K. 2000: Prochristianella spinulifera n. sp. (Cestoda: Trypanorhyncha) from Australian dasyatid and rhinobatid rays. Syst. Parasitol. 47: 1-8.

Beveridge I., Smith K. 1985: An ultrastructural study of the cirrus and vagina of Phyllobothrium vagans (Cestoda: Tetraphyllidea). Z. Parasitenkd. 71: 609-616.

Biserova N.M. 1991: [Ultrastructure of scolex and the tegument of the strobila in Echinobothrium typus (Cestoda: Diphyllidea).] Tr. Zool. Inst. Acad. Sci. USSR 241: 153-172. (In Russian.) 
Blitz N.M., Sмyth J.D. 1973: Tegumental ultrastructure of Raillietina cesticillus during the larval-adult transformation, with emphasis on the rostellum. Int. J. Parasitol. 3: 561-570.

Borror D.J. 1960: Dictionary of Word Roots and Combining Forms: Compiled from the Greek, Latin, and other Languages, with Special Reference to Biological Terms and Scientific Names. N-P Publications, Palo Alto, California, 134 pp.

Bortoletti G., Ferretti G. 1985: Morphological studies on the early development of Taenia taeniaeformis larvae in susceptible mice. Int. J. Parasitol. 15: 365-375.

BOYCE N.P. 1976: A new organ in cestode surface ultrastructure. Can. J. Zool. 54: 610-613.

BRATEN T. 1968a: An electron microscope study of the tegument and associated structures of the procercoid of Diphyllobothrium latum (L.). Z. Parasitenkd. 30: 95-103.

BRATEN T. 1968b: The fine structure of the tegument of Diphyllobothrium latum (L.): A comparison of the plerocercoid and adult stages. Z. Parasitenkd. 30: 104-112.

BRockerhoff A., Jones M.K. 1995: Ultrastructure of the scolex and tentacles of the metacestode of Polypocephalus species (Cestoda: Lecanicephalidae) from the blue-swimmer crab Portunus pelagicus. Int. J. Parasitol. 25: 1077-1088.

Brown R.W. 1956: Composition of Scientific Words: A Manual of Methods and a Lexicon of Materials for the Practice of Logotechnics. Smithsonian Institution Press, Washington, D.C., 882 pp.

Bruñanská A.M., Fagerholm H.-P., Gustafsson M.K.S. 2000: Ultrastructure studies of preadult Proteocephalus longicollis (Cestoda, Proteocephalidea): transmission electron microscopy of scolex sensory receptors. Parasitol. Res. 86: 89-95.

Burt M.D.B., Sandeman I.M. 1974: The biology of Bothrimonus (=Diplocotyle) (Pseudophyllidea: Cestoda): detailed morphology and fine structure. J. Fish. Res. Board Can. 31: 147-153.

CAIRA J.N. 1990a: The tapeworm Spiniloculus mavensis (Tetraphyllidea: Onchobothriidae) from the brownbanded bambooshark in Australia. Aust. J. Zool. 37: 705-710.

CAIRA J.N. 1990b: Scolex microtriches as systematic characters in the Onchobothriidae. Bull. Soc. Zool. Fr. 8: 212.

CAIRA J.N. 1992: Verification of multiple species of Pedibothrium in the Atlantic nurse shark with comments on the Australasian members of the genus. J. Parasitol. 78: 289-308.

Caira J.N., Burge A.N. 2001: Three new species of Acanthobothrium (Cestoda: Tetraphyllidea) from the ocellated electric ray, Diplobatis ommata, in the Gulf of California, Mexico. Comp. Parasitol. 68: 52-65.

CAira J.N., Durkin S.M. 2006: A new genus and species of tetraphyllidean cestode from the spadenose shark, Scoliodon laticaudus, in Malaysian Borneo. Comp. Parasitol. 73: 42-48.

Caira J.N., Healy C.J., Swanson J. 1996: A new species of Phoreiobothrium (Cestoidea: Tetraphyllidea) from the great hammerhead shark Sphyrna mokarran and its implications for the evolution of the onchobothriid scolex. J. Parasitol. 82: 458462 .

Caira J.N., Jensen K., Healy C.J. 1999: On the phylogenetic relationships among tetraphyllidean, lecanicephalidean and diphyllidean tapeworm genera. Syst. Parasitol 42: 77-151.

Caira J.N., Jensen K., Healy C.J. 2001: Interrelationships among tetraphyllidean and lecanicephalidean cestodes. In: D.T.J. Littlewood and R.A. Bray (Eds.), Interrelationships of the Platyhelminthes. Taylor \& Francis, London and New York, pp. 135158.

Caira J.N., Jensen K., Rajan C. 2007a: Seven new Yorkeria species (Cestoda: Tetraphyllidea) from Borneo and Australia and their implications for identification of Chiloscyllium (Elasmobranchii: Orectolobiformes) species. J. Parasitol. 93: 357-376.

Caira J.N., Keeling C.P. 1996: On the status of the genus Pinguicollum (Tetraphyllidea: Onchobothriidae) with a redescription of P. pinguicollum. J. Parasitol. 82: 463-469.

Caira J.N., Mega J., Ruhnke T.R. 2005: An unusual blood sequestering tapeworm (Sanguilevator yearsleyi n. gen., n. sp.) from Borneo with description of Cathetocephalus resendezi n. sp. from Mexico and molecular support for the recognition of the order Cathetocephalidea (Platyhelminthes: Eucestoda). Int. J. Parasitol. 35: 1135-1152.

Caira J.N., Orringer D.V. 1995: Additional information on the morphology of Potamotrygonocestus magdalenensis (Tetraphyllidea: Onchobothriidae) from the freshwater stingray Potamotrygon magdalenae in Colombia. J. Helminthol. Soc. Wash. 62: $22-26$.

Caira J.N., Pritchard M.H. 1986: A review of the genus Pedibothrium Linton, 1909 (Tetraphyllidea: Onchobothriidae) with description of two new species and comments on the related genera Pachybothrium Baer and Euzet, 1962 and Balanobothrium Hornell, 1912. J. Parasitol. 72: 62-70.

Caira J.N., Reyda F.B., Mega J.D. 2007b: A revision of Megalonchos (Tetraphyllidea: Onchobothriidae) with description of two new species and transfer of two species to Biloculuncus. Syst. Parasitol. 67: 211-223.

CAira J.N., RuhnKe T.R. 1990: A new species of Calliobothrium (Tetraphyllidea: Onchobothriidae) from the whiskery shark, Furgaleus macki, in Australia. J. Parasitol. 76: 319-324.

CAira J.N., RuhnKe T.R. 1991: A comparison of scolex morphology between the plerocercoid and the adult of Calliobothrium verticillatum (Tetraphyllidea: Onchobothriidae). Can. J. Zool. 69: 1484-1488.

Caira J.N., Tracy R. 2002: Two new species of Yorkeria (Tetraphyllidea: Onchobothriidae) from Chiloscyllium punctatum (Elasmobranchii: Hemiscylliidae) in Thailand. J. Parasitol. 88: $1172-1180$.

Caira J.N., Tracy R., Euzet L. 2004: Five new species of Pedibothrium (Tetraphyllidea: Onchobothriidae) from the tawny nurse shark, Nebrius ferrugineus, in the Pacific Ocean. J. Parasitol. 90: 286-300.

Caira J.N., Zahner S.D. 2001: Two new species of Acanthobothrium Beneden, 1849 (Tetraphyllidea: Onchobothriidae) from horn sharks in the Gulf of California, Mexico. Syst. Parasitol. 50: 219-229.

Campbell R.A., Marques F., Ivanov V.A. 1999: Paroncomegas araya (Woodland, 1934) n. gen. et comb. (Cestoda: Trypanorhyncha: Eutetrarhynchidae) from the freshwater stingray Potamotrygon motoro in South America. J. Parasitol. 85: 313-320.

Cañeda-Guzmán I.C., de Chambrier A., Scholz T. 2001: Thaumasioscolex didelphidis n. gen., n. sp. (Eucestoda: Proteocephalidae) from the black-eared opossum Didelphis marsupialis from Mexico, the first proteocephalidean tapeworm from a mammal. J. Parasitol. 87: 639-646.

Carvajal J., Barros C., Whittaker F.H. 1987: Scanning electron microscopy of the scolex of the plerocercus Callitetrarhynchus gracilis (Rudolphi, 1819) (Cestoda: Trypanorhyncha). J. Parasitol. 73: 1265-1267.

Casado N., Pérez-Serrano J., Denegri G., Rodríguez-CaabeiRO F. 1994: Development of truncated microtriches in Echinococcus granulosus protoscolices. Parasitol. Res. 80: 355-357.

Casado N., Urrea M.A., Moreno M.J., Rodríguez-CaAbeiro F. 1999: Tegumental topography of the plerocercoid of Gymno- 
rhynchus gigas (Cestoda: Trypanorhyncha). Parasitol. Res. 85: 124-130.

Charles G.H., OrR T.S.C. 1968: Comparative fine structure of outer tegument of Ligula intestinalis and Schistocephalus solidus. Exp. Parasitol. 22: 137-149.

Chervy L. 2002: The terminology of larval cestodes or metacestodes. Syst. Parasitol. 52: 1-33.

Chubb J.C., Seppala T., Luscher A., Milinski M., Valtonen E.T. 2006: Schistocephalus cotti n. sp. (Cestoda: Pseudophyllidea) plerocercoids from bullheads Cottus gobio L. in an Artic river in Finland, with a key to the plerocercoids of the Palaearctic species of the genus. Syst. Parasitol. 65: 161-170.

Cielecka D., Grytner-Zięcina B., Chomicz L. 1994: Studies of the surface ultrastructure of Sobolevicanthus gracilis (Zeder, 1803) (Cestoda, Hymenolepididae). Acta Parasitol. 39: 131-137.

Clopton R.E. 2004: Standard nomenclature and metrics of plane shapes for use in gregarine taxonomy. Comp. Parasitol. 71: $130-140$.

Coggins J.R. 1980: Tegument and apical end organ fine structure in the metacestode and adult Proteocephalus ambloplitis. Int. J. Parasitol. 10: 409-418.

CoIL W.H. 1991: Platyhelminthes: Cestoidea. In: F.W. Harrison and B.J. Bogitsch (Eds.), Microscopic Anatomy of Invertebrates, Volume 3: Platyhelminthes and Nemertinea. John Wiley \& Sons, Inc., New York, pp. 219-225.

ConN D.B. 1988: Fine structure of the tegument of Mesocestoides lineatus tetrathyridia (Cestoda: Cyclophyllidea). Int. J. Parasitol. 18: 133-135.

Conn D.B. 2004: Comparative aspects of postembryonic development of cestodes (Platyhelminthes) and other animal taxa. In: S. Mas-Coma (Ed.), Multidisciplinarity for Parasites, Vectors and Parasitic Diseases. Proceedings of the IX European Multicolloquium of Parasitology. Vol. 1. Articles of Keynote Speakers. Monduzzi Editore, Bologna, Italy, pp. 319-325.

Conn D.B., Świderski Z. 2008: A standardised terminology of the embryonic envelopes and associated developmental stages of tapeworms (Platyhelminthes: Cestoda). Folia Parasitol. 55: $42-52$.

Coutelen F. 1927: Contribution a l'étude morphologique des scolex échinococciques. Ann. Parasitol. Hum. Comp. 5: 243-244.

Crusz H. 1947: The early development of the rostellum of Cysticercus fasciolaris Rud., and the chemical nature of its hooks. J. Parasitol. 33: 87-98.

Czaplinski B., Aeschlimann A., Cielecka D. 1984: Scanning electron microscopy of the cirrus surface of some Hymenolepididae (Cestoda). Acta Parasitol. Pol. 29: 59-62.

Czaplinski B., Cielecka D., Aeschlimann A. 1988: Some ultrastructural comparative data on Diorchis inflata (Rudolphi, 1819) and D. ransomi Johri, 1939 (Cestoda, Hymenolepididae) in scanning electron microscopy. Acta Parasitol. Pol. 33: 123125.

Davydov V.G., Korneva J.V., Kuperman B.I. 1995: The development of the tegument in ontogenesis of Triaenophorus nodulosus (Cestoda: Pseudophyllidea). Folia Parasitol. 42: 269-279.

Davydov V.G., Kuperman B.I. 1993: The ultrastructure of the tegument and the peculiarities of the biology of Amphilina foliacea adult (Plathelminthes, Amphilinidea). Folia Parasitol. 40: 13-22.

Davydov V.G., Poddubnaya L.G., Kuperman B.I. 1997: An ultrastructure of some systems of Diplocotyle olrikii (Cestoda: Cyathocephalata) in relation to peculiarities of its life cycle. Parazitologiya 31: 132-141. (In Russian with English summary.)

Davydov V.G., Pospekhova N.A., Yurlova N.I. 1990: Ultrastructural organisation of scolex and strobila in Gastrotaenia dogieli
(Cestoda, Hymenolepididae). Parazitologiya 24: 207-215. (In Russian with English summary.)

De Chambrier A. 2001: A new tapeworm from the Amazon, Amazotaenia yvettae gen. n., sp. n., (Eucestoda: Proteocephalidea) from the siluriform fishes Brachyplatystoma filamentosum and B. vaillanti (Pimelodidae). Rev. Suisse Zool. 108: 303-316.

de Chambrier A. 2003: Systematic status of Manaosia bracodemoca Woodland, 1935 and Paramonticellia itaipuensis Pavanelli et Rego, 1991 (Eucestoda: Proteocephalidea), parasites of Sorubim lima (Siluriformes: Pimelodidae) from South America. Folia Parasitol. 50: 121-127.

De Chambrier A. 2004: Redescription of Ophiotaenia hylae Johnston, 1912 (Eucestoda: Proteocephalidea), parasite of Litoria aurea (Amphibia: Hylidae) from Australia. Rev. Suisse Zool. 111: 371-380.

DE Chambrier A. 2006: Redescription of Kapsulotaenia sandgroundi (Carter, 1943) (Eucestoda: Proteocephalidea: Acanthotaeniinae), a parasite of Varanus komodoensis (Varanoidea: Varanidae) from Indonesia. Syst. Parasitol. 63: 83-93.

de Chambrier A., Al-Kallak S.N.H., Mariaux J. 2003: A new tapeworm, Postgangesia inarmata n. sp. (Eucestoda: Proteocephalidea: Gangesiinae), parasitic in Silurus glanis (Siluriformes) from Iraq and some comments on the Gangesiinae Mola, 1929. Syst. Parasitol. 55: 199-209.

de Chambrier A., Coquille S.C., Brooks D.R. 2006b: Ophiotaenia bonneti sp. n. (Eucestoda: Proteocephalidea), a parasite of Rana vaillanti (Anura: Ranidae) in Costa Rica. Folia Parasitol. 53: $125-133$.

de Chambrier A., Coquille S.C., Tkach V., Mariaux J. 2009a: Redescription of Testudotaenia testudo (Magath, 1924) (Eucestoda: Proteocephalidea), a parasite of Apalone spinifera (Le Sueur) (Reptilia: Trionychidae) and Amia calva L. (Pisces: Amiidae) in North America and erection of the Testudotaeniinae $n$. subfam. Syst. Parasitol. 73: 49-64.

de Chambrier A., Mariaux J., Sène A., Mahmoud Z.N., Scholz T. 2008: Sandonella sandoni (Lynsdale, 1960), an enigmatic and morphologically unique cestode parasitic in the osteoglossiform fish Heterotis niloticus in Africa. J. Parasitol. 94: 202-211.

de Chambrier A., Rego A.A., Gil de Pertierra A.A. 2005: Redescription of two cestodes (Eucestoda: Proteocephalidea) parasitic in Phractocephalus hemioliopterus (Siluriformes) from the Amazon and erection of Scholzia gen. n. Rev. Suisse Zool. 112: 735-752.

de Chambrier A., Rego A.A., Vaucher C. 1999: Euzetiella tetraphylliformis n. gen., n. sp., (Eucestoda: Proteocephalidea), parasite du poisson d'eau douce néotropical Paulicea luetkeni (Siluriformes, Pimelodidae). Parasite 6: 43-47.

de Chambrier A., Scholz T. 2008: Tapeworms (Cestoda: Proteocephalidea) of firewood catfish Sorubimichthys planiceps (Siluriformes: Pimelodidae) from the Amazon River. Folia Parasitol. 55: 17-28.

de Chambrier A., Scholz T., Beletew M., Mahmoud Z.N. 2007: Redescription of Proteocephalus sulcatus (Klaptocz, 1906) (Cestoda: Proteocephalidea), a poorly known parasite of Clarotes laticeps (Pisces: Siluriformes) in the Sudan. Rev. Suisse Zool. 114: 693-702.

de Chambrier A., Scholz T., Beletew M., Mariaux J. 2009b: A new genus and species of proteocephalidean (Cestoda) from Clarias catfishes (Siluriformes: Clariidae) in Africa. J. Parasitol. 95: $160-168$.

de Chambrier A., Scholz T., Ibraheem M.H. 2004: Redescription of Electrotaenia malopteruri (Fritsch, 1886) (Cestoda: Proteo- 
cephalidae), a parasite of Malapterurus electricus (Siluriformes: Malapteruridae) from Egypt. Syst. Parasitol. 57: 97-109.

de Chambrier A., Takemoto R.M., Pavanelli G.C. 2006a: Nomimoscolex pertierrae n. sp. (Eucestoda: Proteocephalidea), a parasite of Pseudoplatystoma corruscans (Siluriformes: Pimelodidae) in Brazil and redescription of $N$. sudobim Woodland, 1935, a parasite of P. fasciatum. Syst. Parasitol. 64: 191-202.

Diaz-Castañeda V., Carabez-Trejo A., Lamothe-Argumedo R. 1995: Ultrastructure of the pseudophyllidean cestode Bothriocephalus acheilognathi, parasite of freshwater fish of commercial importance. An. Inst. Biol. Univ. Nac. Auton. Méx., Ser. Zool., 66: 1-16.

Euzet L., Gabrion C. 1976: Mise en évidence d'un gradient de différenciation du tégument chez la larve de deux Cestodes Cyclophyllides. C. R. Acad. Sci., Sér. D, Sci. Nat. 283: 367-370.

Faliex E., Tyler G., Euzet L. 2000: A new species of Ditrachybothridium (Cestoda: Diphyllidea) from Galeus sp. (Selachii, Scyliorhinidae) from the South Pacific Ocean, with a revision of the diagnosis of the order, family, and genus and notes on descriptive terminology of microtriches. J. Parasitol. 86: 10781084.

Featherston D.W. 1972: Taenia hydatigena - IV. Ultrastructure study of the tegument. Z. Parasitenkd. 38: 214-232.

Featherston D.W. 1975: Taenia hydatigena - V. Surface structure of the adult worm and evaginated scolex. Int. J. Parasitol. 5: 615-619.

Fourie H.J., Van Amelsfoort A.F., Michael L.M., Putterill J.F. 1997: A scanning electron-microscope examination of the scolex of Houttuynia struthionis. Onderstepoort J. Vet. Res. 64: $47-50$.

FyLER C.A. 2007: Comparison of microthrix ultrastructure and morphology on the plerocercoid and adult scolex of Calliobothrium cf. verticillatum (Tetraphyllidea: Onchobothriidae). J. Parasitol. 93: 4-11.

Fyler C.A., Caira J.N. 2006: Five new species of Acanthobothrium (Tetraphyllidea: Onchobothriidae) from the freshwater stingray Himantura chaophraya (Batoidea: Dasyatidae) in Malaysian Borneo. J. Parasitol. 92: 105-125.

Gabrion C. 1982: Origine du tégument définitif chez les cestodes cyclophyllides. Bull. Soc. Zool. Fr. 107: 565-569.

Gabrion C., EuZet-Sicard S. 1979: Étude du tégument et des récepteurs sensoriels du scolex d'un plérocercoïde de Cestode Tetraphyllidea à l'aide de la microscopie électronique. Ann. Parasitol. Hum. Comp. 54: 573-583.

Ghoshroy S., Caira J.N. 2001: Four new species of Acanthobothrium (Cestoda: Tetraphyllidea) from the whiptail stingray Dasyatis brevis in the Gulf of California, Mexico. J. Parasitol. 87: 354-372.

Gijon-Botella H., Del Castillo-Remiro J.A., López-Román R. 1989: Estudio al M.E.B. de Raillietina (Raillietina) micracantha Fuhrmann, 1908 parásito de Columba livia domestica capturadas en las Islas Canarias. Rev. Iber. Parasitol. 49: 37-40.

Gil de Pertierra A.A. 2002: Nomimoscolex semenasae n. sp. (Proteocephalidea, Monticelliidae), a cestode parasite of Diplomystes viedmensis (Pisces: Siluriformes) from the Patagonian region of Argentina. Syst. Parasitol. 53: 183-190.

Gil de Pertierra A.A. 2004: Redescription of Monticellia magna (Rego, dos Santos \& Silva, 1975) (Eucestoda: Monticelliidea) parasite of Pimelodus spp. (Pisces: Siluriformes) from Argentina, and morphological study of microtriches. Rev. Suisse Zool. 111: 11-20.

Gil de Pertierra A.A. 2005: Comparative study of the microtriches of adult cestodes (Proteocephalidea: Monticelliidae), and some comments on their systematic value. Zool. Anz. 243: 295-304.

Gil de Pertierra A.A. 2009: Lucieaella ivanovae n. gen., n. sp. (Eucestoda: Proteocephalidea: Peltidocotylinae), a parasite of Ageneiosus inermis (L.) (Siluriformes: Auchenipteridae) in Argentina. Syst. Parasitol. 73: 71-80.

Gil de Pertierra A.A., de Chambrier A. 2000: Rudolphiella szidati sp. n. (Proteocephalidea: Monticelliidae, Rudolphielliinae) parasite of Luciopimelodus pati (Valenciennes, 1840) (Pisces: Pimelodidae) from Argentina with new observations on $\mathrm{Ru}$ dolphiella lobosa (Riggenbach, 1895). Rev. Suisse Zool. 107: 81-95.

Gil de Pertierra A.A., Semenas L.G. 2005: Galaxitaenia tolo n. gen., n. sp. (Eucestoda: Pseudophyllidea) from Galaxias platei (Pisces: Osmeriformes, Galaxiidae), in the Patagonian region of Argentina. J. Parasitol. 91: 900-908.

Gil de Pertierra A.A., Semenas L.G. 2006: Ailinella mirabilis gen. n., sp. n. (Eucestoda: Pseudophyllidea) from Galaxias maculatus (Pisces: Galaxiidae) in the Andean-Patagonian region of Argentina. Folia Parasitol. 53: 276-286.

Goldschmidt R. 1900: Zur Entwicklungsgeschichte der Echinococcusköpfchen. Zool. Jahrb. 13: 467-494.

GrammeltvedT A.F. 1973: Differentiation of the tegument and associated structures in Diphyllobothrium dendriticum Nitzsch (1824) (Cestoda: Pseudophyllidea). An electron microscopical study. Int. J. Parasitol. 3: 321-327.

Granath W.O., Lewis J.C., Esch G.W. 1983: An ultrastructural examination of the scolex and tegument of Bothriocephalus acheilognathi (Cestoda: Pseudophyllidea). Trans. Am. Microsc. Soc. 102: 240-250.

Grytner-Zięcina B., Cielecka D., Chomicz L. 1995: Transmission electron microscopy studies on the tegument of two species of genus Fimbriaria Froelich, 1802. Acta Parasitol. 40: 88-93.

HALton D.W. 1982: Morphology and ultrastructure of parasitic helminths. In: D.F. Mettrick and S.S. Desser (Eds.), Parasites - Their World and Ours. Proceedings of the Fifth International Congress of Parasitology held in Toronto, Canada. Elsevier Biomedical Press, Amsterdam, pp. 60-69.

Halton D.W., McKerr G. 1979: SEM observations on the spiral valve of rays and their cestode parasites. Parasitology 79: 47.

Hanzelová V., Scholz T., Fagerholm H.-P. 1995: The synonymy of the Proteocephalus neglectus La Rue, 1911 with P. exiguus La Rue, 1911, two fish cestodes from the Holarctic Region. Syst. Parasitol. 30: 173-185.

Harris A., Heath D.D., Lawrence S.B., Shaw R.J. 1989: Echinococcus granulosus: ultrastructure of epithelial changes during the first 8 days of metacestode development in vitro. Int. J. Parasitol. 19: 621-629.

HAYUNGA E.G. 1991: Morphological adaptations of intestinal helminths. J. Parasitol. 77: 865-873.

Hayunga E.G., Mackiewicz J.S. 1975: An electron microscope study of the tegument of Hunterella nodulosa Mackiewicz and McCrae, 1962 (Cestoidea: Caryophyllidea). Int. J. Parasitol. 5: 309-319.

Healy C.J. 2003: A revision of Platybothrium Linton, 1890 (Tetraphyllidea: Onchobothriidae), with a phylogenetic analysis and comments on host-parasite associations. Syst. Parasitol. 56: $85-139$.

Healy C.J. 2006a: Three new species of Rhinebothrium (Cestoda: Tetraphyllidea) from the freshwater whipray, Himantura chaophraya, in Malaysian Borneo. J. Parasitol. 92: 364-374.

Healy C.J. 2006b: A revision of selected Tetraphyllidea (Cestoda): Caulobothrium, Rhabdotobothrium, Rhinebothrium, Scalithri- 
um, and Spongiobothrium. PhD Thesis, University of Connecticut, $382 \mathrm{pp}$.

Hess E. 1980: Ultrastructural study of the tetrathyridium of Mesocestoides corti Hoeppli, 1925: tegument and parenchyma. Z. Parasitenkd. 61: 135-159.

Hess E., Guggenheim R. 1977: A study of the microtriches and sensory processes of the tetrathyridium of Mesocestoides corti Hoeppli, 1925, by transmission and scanning electron microscopy. Z. Parasitenkd. 53: 189-199.

Hildreth M.B., Lumsden R.D. 1987: Microanatomy of the Otobothrium insigne plerocercus (Cestoda: Trypanorhyncha). J. Parasitol. 73: 400-410.

Hoberg E.P., Sims D.E., Odense P.H. 1995: Comparative morphology of the scolices and microtriches among five species of Tetrabothrius (Eucestoda: Tetrabothriidae). J. Parasitol. 81: 475-481.

Holcman B., Heath D.D. 1997: The early stages of Echinococcus granulosus. Acta Trop. 64: 5-17.

Holy J.M., OAKs J.A. 1986: Ultrastructure of the tegumental microvilli (microtriches) of Hymenolepis diminuta. Cell Tissue Res. 244: 457-466

Howells R.E. 1965: Electron-microscope and histochemical studies on the cuticle and subcuticular tissues of Moniezia expansa. Parasitology 55: 20P-21P.

HulíNSKÁ D. 1977a: An electron microscope study on the bladder surface of early developmental stages of Cysticercus tenuicollis. Folia Parasitol. 24: 261-264.

HuLÍNSKÁ D. 1977b: The fine structure and histochemistry of bleblike extrusions in the microthrix border of the larval Multiceps endothoracicus. Folia Parasitol. 24: 25-33.

HulínSKÁ D. 1978: Fine structure of cells and tissues of Cysticercus tenuicollis aged 13 and 16 days. Folia Parasitol. 25: 339-345.

HuLíNSKÁ D. 1980: The morphogenesis of microtriches in the tegument of Taenia hydatigena throughout its larval development. Folia Parasitol. 27: 329-336.

HulínSKÁ D. 1981: Scanning electron microscopy of the surface of the adult Multiceps endothoracicus and a comparison of its larval and adult scoleces. Folia Parasitol. 28: 349-352.

HulínsKá D., Lavrov V.I. 1981: Morphology and cytochemistry of the adult tapeworm Multiceps endothoracicus with emphasis on the scolex. Folia Parasitol. 28: 227-234.

Hyman L. 1951: The Invertebrates. Vol. II. Platyhelminthes and Rhynchocoela. McGraw-Hill Book Company, Inc., New York, $572 \mathrm{pp}$.

Irshadullah M., Nazimi W.A., Ahmad M. 1990: Polymorphism in the microtriches of adult Echinococcus granulosus: scanning electron microscopy. Zool. Anz. 224: 321-327.

Ishil A.I., Muranaka Y., SAno M. 1988: Ultrastructures of Diplogonoporus grandis microthrix. Jpn. J. Parasitol. 37: 178-181.

Ivanov V.A. 2004: A new species of Rhinebothroides Mayes, Brooks \& Thorson, 1981 (Cestoda: Tetraphyllidea) from the ocellate river stingray in Argentina, with amended descriptions of two other species of the genus. Syst. Parasitol. 58: 159-174.

Ivanov V.A. 2005: A new species of Acanthobothrium (Cestoda: Tetraphyllidea: Onchobothriidae) from the ocellate river stingray, Potamotrygon motoro (Chondrichthyes: Potamotrygonidae), in Argentina. J. Parasitol. 91: 390-396.

Ivanov V.A. 2006: Guidus n. gen. (Cestoda: Tetraphyllidea), with description of a new species and emendation of the generic diagnosis of Marsupiobothrium. J. Parasitol. 92: 832-840.

Ivanov V.A. 2008: Orygmatobothrium spp. (Cestoda: Tetraphyllidea) from triakid sharks in Argentina: redescription of Orygma- tobothrium schmittii and description of a new species. J. Parasitol. 94: 1087-1097.

Ivanov V.A., Brooks D.R. 2002: Calliobothrium spp. (Cestoda: Tetraphyllidea: Onchobothriidae) from Mustelus schmitti (Chondrichthyes: Carcharhiniformes) in Argentina and Uruguay. J. Parasitol. 88: 1200-1213.

Ivanov V.A., Campbell R.A. 1998a: Echinobothrium megacanthum sp. n. (Cestoda: Diphyllidea) from the eagle ray Myliobatis goodei (Chondrichthyes: Rajoidei) from the Patagonian shelf of Argentina. Folia Parasitol. 45: 225-229.

Ivanov V.A., Campbell R.A. 1998b: A new species of Acanthobothrium van Beneden, 1849 (Cestoda: Tetraphyllidea) from Rioraja castelnaui (Chondrichthyes: Rajoidei) in coastal waters of Argentina. Syst. Parasitol. 40: 203-212.

Ivanov V.A., Campbell R.A. 2000: Emendation of the generic diagnosis of Tylocephalum (Cestoda: Lecanicephalidea: Tetragonocephalidae), and description of Tylocephalum brooksi n. sp. J. Parasitol. 86: 1085-1095.

Ivanov V.A., CAmpBell R.A. 2002: Notomegarhynchus navonae n. gen. and n. sp. (Eucestoda: Tetraphyllidea), from skates (Rajidae: Arhynchobatinae) in the Southern Hemisphere. J. Parasitol. 88: 340-349.

Ivanov V.A., Lipshitz A. 2006: Description of a new diphyllidean parasite of triakid sharks from the deep Red Sea. J. Parasitol. 92: 841-846.

Jarecka L., Michajlow W., Burt M.D.B. 1981: Comparative ultrastructure of cestode larvae and Janicki's cercomer theory. Acta Parasitol. Pol. 28: 65-72.

JeNSEN K. 2001: Four new genera and five new species of lecanicephalideans (Cestoda: Lecanicephalidea) from elasmobranchs in the Gulf of California, Mexico. J. Parasitol. 87: 845-861.

Jensen K. 2005: A Monograph on the Lecanicephalidea (Platyhelminthes, Cestoda). Tapeworms of Elasmobranchs Part I. University of Nebraska State Museum, Lincoln, Nebraska, 241 pp.

Jensen K. 2006: A new species of Aberrapex Jensen, 2001 (Cestoda: Lecanicephalidea) from Taeniura lymma (Forsskål) (Myliobatiformes: Dasyatidae) from off Sabah, Malaysia. Syst. Parasitol. 64: 117-123.

Jensen K., Caira J.N. 2006: The status of Rhoptrobothrium Shipley et Hornell, 1906 (Cestoda: Tetraphyllidea), with redescription of the type species, $R$. myliobatidis, and description of three new species from two species of Aetomylaeus (Myliobatiformes: Myliobatidae) from Malaysian Borneo. Folia Parasitol. 53: 189207.

Jensen K., Caira J.N. 2008: A revision of Uncibilocularis Southwell, 1925 (Tetraphyllidea: Onchobothriidae) with the description of four new species. Comp. Parasitol. 75: 157-173.

Jha R.K., Sмүтн J.D. 1969: Echinococcus granulosus: ultrastructure of microtriches. Exp. Parasitol. 25: 232-244.

JhA R.K., Sмyтн J.D. 1971: Ultrastructure of the rostellar tegument of Echinococcus granulosus with special reference to biogenesis of mitochondria. Int. J. Parasitol. 1: 169-177.

JiLEK R., CRITES J.L. 1980: Scanning electron microscopic examination of the scolex and external tegumental surface of Proteocephalus ambloplitis. J. Microsc. 118: 443-446.

JoNES A. 1975: The morphology of Bothriocephalus scorpii (Müller) (Pseudophyllidea, Bothriocephalidae) from littoral fishes in Britain. J. Helminthol. 49: 251-261.

JonES M.K. 1989: Ultrastructure of the cirrus pouch of Cylindrotaenia hickmani (Jones, 1985) (Cestoda, Nematotaeniidae). Int. J. Parasitol. 19: 919-930.

JoNES M.K. 1998: Structure and diversity of cestode epithelia. Int. J. Parasitol. 28: 913-923. 
JONES M.K. 2000: Ultrastructure of the scolex, rhyncheal system and bothridial pits of Otobothrium mugilis (Cestoda: Trypanorhyncha). Folia Parasitol. 47: 29-38.

Jones M.K., Beveridge I. 1998: Nybelinia queenslandensis sp. $\mathrm{n}$. (Cestoda: Trypanorhyncha) parasitic in Carcharhinus melanopterus, from Australia, with observations on the fine structure of the scolex including the rhyncheal system. Folia Parasitol. 45: 295-311.

Kent H.N. 1957: Aspect biochimique de la spécificité chez les cestodes. In: J. Baer (Ed.), First Symposium on Host Specificity Among Parasites of Vertebrates. Int. Union Biol. Sci. and University of Neuchâtel, Neuchâtel, Switzerland, pp. 293-309.

Kuchta R., Scholz T. 2008: A new triaenophorid tapeworm from blackfish Centrolophus niger. J. Parasitol. 94: 500-504.

Kuchta R., Scholz T., Brabec J., Jirsová D., Gustinelli A. 2008a: Bothriocephalidean tapeworms (Cestoda) from the blackfish, Centrolophus niger (Perciformes: Centrolophidae). Folia Parasitol. 55: 111-121.

Kuchta R., Scholz T., Bray R.A. 2008b: Revision of the order Bothriocephalidea Kuchta, Scholz, Brabec \& Bray, 2008 (Eucestoda) with amended generic diagnoses and keys to families and genera. Syst. Parasitol. 71: 81-136.

Kuchta R., Scholz T., Vlčková R., Říha M., Walter T., Yuniar A.T., PaLm H.W. 2009: Revision of tapeworms (Cestoda: Bothriocephalidea) from lizardfish (Saurida: Synodontidae) from the Indo-Pacific region. Zootaxa 1977: 55-67.

Kuperman B.I. 1980: Fine structure of cestode tegument and its significance for systematics. Parazitol. Sb. 29: 84-95. (In Russian, with English summary.)

Kuperman B.I. 1988: Functional Morphology of Lower Cestodes: Ontogenetic and Evolutionary Aspects. Nauka, Leningrad, 167 pp. (In Russian with English summary.)

KwA B.H. 1972: Studies on the sparganum of Spirometra erina$c e i-$ III. The fine structure of the tegument in the scolex. Int. J. Parasitol. 2: 35-43.

LEE D.L. 1966: The structure and composition of the helminth cuticle. In: B. Dawes (Ed.), Advances in Parasitology, Vol. 4. Academic Press, London, pp. 187-254.

Leuckart R. 1886: Parasites of man and the diseases which proceed from them. Pentland, Edinburgh, p. 269-295.

Levron C., Poddubnaya L.G., Kuchta R., Freeman M., Wang Y.-H., Scholz T. 2008a: Ultrastructure of the tegument of the cestode Paraechinophallus japonicus (Bothriocephalidea: Echinophallidae), a parasite of the bathypelagic fish Psenopsis anomala. Invertebr. Biol. 127: 153-161.

Levron C., Poddubnaya L.G., Kuchta R., Freeman M., Wang Y.-H., Scholz T. 2008b: First SEM and TEM study of the armed male terminal genitalia of the tapeworm Paraechinophallus japonicus (Cestoda: Bothriocephalidea). J. Parasitol. 94: 803-810.

Levron C., Scholz T., Dezfuli B.S. 2008c: Ultrastructure of microtriches on the scolex of Cyathocephalus truncatus (Cestoda: Spathebothriidea). Folia Parasitol. 55: 309-312.

LuMSDEN R.D. 1966: Cytological studies on the absorptive surfaces of cestodes. I. The fine structure of the strobilar integument. Z. Parasitenkd. 27: 355-382.

LUMSDEN R.D. 1975a: Surface ultrastructure and cytochemistry of parasitic helminths. Exp. Parasitol. 37: 267-339.

LuMSDEN R.D. 1975b: The tapeworm tegument: a model system for studies on membrane structure and function in host-parasite relationships. Trans. Am. Microsc. Soc. 94: 501-507.
Lumsden R.D., Gonzalez G., Mills R.R., Viles J.M. 1968: Cytological studies on the absorptive surfaces of cestodes. III. Hydrolysis of phosphate esters. J. Parasitol. 54: 524-535.

Lumsden R.D., Hildreth M.B. 1983: The fine structure of adult tapeworms. In: C. Arme and P.W. Pappas (Eds.), Biology of the Eucestoda, Vol. 1. Academic Press, London, New York, pp. 182-191.

Lumsden R.D., Murphy W.A. 1980: Morphological and functional aspects of the cestode surface. In: C.B. Cook, P.W. Pappas and E.D. Rudolph (Eds.), Cellular Interactions in Symbiosis and Parasitism. Ohio State University Press, Columbus, pp. 95-130.

Lumsden R.D., OAKs J.A., Mueller J.F. 1974: Brush border development in the tegument of the tapeworm, Spirometra mansonoides. J. Parasitol. 60: 209-226.

Lumsden R.D., Specian R. 1980: The morphology, histology and fine structure of the adult stage of the cyclophyllidean tapeworm Hymenolepis diminuta. In: H.P. Arai (Ed.), Biology of the Tapeworm Hymenolepis diminuta. Academic Press, New York, pp. $157-280$.

Lyngdoh R.D., Tandon V. 1996: Surface topographical and ultrastructural studies on a caryophyllidean cestode, Lytocestus indicus (Lytocestidae). J. Parasitol. Appl. Anim. Biol. 5: 67-74.

Lyons K.M. 1969: The fine structure of the body wall of Gyrocotyle urna. Z. Parasitenkd. 33: 95-109.

MACKIEWICZ J.S. 1972: Caryophyllidea (Cestoidea): a review. Exp. Parasitol. 31: 417-512.

MacKinnon B.M., Burt M.D.B. 1983: Polymorphism of microtriches in the cysticercoid of Ophryocotyle insignis Lönnberg, 1890 from the limpet Patella vulgata. Can. J. Zool. 61: 10621070.

MacKinnon B.M., Burt M.D.B. 1984: The development of the tegument and cercomer of the polycephalic larvae (cercoscolices) of Paricterotaenia paradoxa (Rudolphi, 1802) (Cestoda: Dilepididae) at the ultrastructural level. Parasitology 88: 117130.

MacKinnon B.M., Burt M.D.B. 1985a: Histological and ultrastructural observations on the secondary scolex and strobila of Haplobothrium globuliforme (Cestoda: Haplobothrioidea). Can. J. Zool. 63: 1995-2000.

MacKinnon B.M., Burt M.D.B. 1985b: The comparative ultrastructure of the plerocercoid and adult primary scolex of Haplobothrium globuliforme Cooper, 1914 (Cestoda: Haplobothrioidea). Can. J. Zool. 63: 1488-1496.

MacKinnon B.M., JARECKA L., BuRT M.D.B. 1985: Ultrastructure of the tegument and penetration glands of developing procercoids of Haplobothrium globuliforme Cooper, 1914 (Cestoda: Haplobothrioidea). Can. J. Zool. 63: 1470-1477.

Marques J.F., Santos M.J., Gibson D.I., Cabral H.N., Olson P.D. 2007: Cryptic species of Didymobothrium rudolphii (Cestoda: Spathebothriidea) from the sand sole, Solea lascaris, off the Portuguese coast, with an analysis of their molecules, morphology, ultrastructure and phylogeny. Parasitology 134: 1057-1072.

McCaig M.L.O., Hopkins C.A. 1965: Studies on Schistocephalus solidus. 3. The in vitro cultivation of the plerocercoid. Parasitology 55: 257-268.

McCullough J.S., Fairweather I. 1983: A SEM study of the cestodes Trilocularia acanthiaevulgaris, Phyllobothrium squali and Gilquinia squali from the spiny dogfish. Z. Parasitenkd. 69: 655-665.

McKenzie V.J., Caira J.N. 1998: Three new genera and species of tapeworms from the longnose sawshark, Pristiophorus cirratus, with comments on their modes of attachment to the spiral intestine. J. Parasitol. 84: 409-421. 
MCVICAR A.H. 1972: The ultrastructure of the parasite-host interface of three tetraphyllidean tapeworms of the elasmobranch Raja naevus. Parasitology 65: 77-88.

Mehlhorn H., Becker B., Andrews P., Thomas H. 1981: On the nature of the proglottids of cestodes: A light and electron microscopic study on Taenia, Hymenolepis, and Echinococcus. Z. Parasitenkd. 65: 243-259.

Menoret A., Ivanov V.A. 2009: A new species of tetraphyllidean (Cestoda) from the largespot river stingray, Potamotrygon falkneri (Potamotrygonidae: Chondrichthyes), from the Parana Basin. J. Parasitol. 95: 994-999.

Mizinska-Boevska Y., Polyakova-Krusteva O., Fok É. 1989: Transmission and scanning electron microscopic observations on the body wall surface of Taenia hydatigena and its metacestode, Cysticercus tenuicollis (Cestoda: Cyclophyllidea). Parasitol. Hung. 22: 57-61.

Moniez R.B. 1881: Mémoires sur les Cestodes. Oct. Doin, Paris, $238 \mathrm{pp}$.

Morris G.P., Finnegan C.V. 1969: Studies of the differentiating plerocercoid cuticle of Schistocephalus solidus. II. The ultrastructural examination of cuticle development. Can. J. Zool. 47: 957-964.

Morseth D.J. 1966: The fine structure of the tegument of adult Echinococcus granulosus, Taenia hydatigena, and Taenia pisiformis. J. Parasitol. 52: 1074-1085.

Morseth D.J. 1967: Fine structure of the hydatid cyst and protoscolex of Echinococcus granulosus. J. Parasitol. 53: 312-325.

Mount P.J. 1970: Histogenesis of rostellar hooks of Taenia crassiceps (Zeder, 1800) (Cestoda). J. Parasitol. 56: 947-961.

Nasin C.S., Caira J.N., Euzet L. 1997: Analysis of Calliobothrium (Tetraphyllidea: Onchobothriidae) with descriptions of three new species and erection of a new genus. J. Parasitol. 83: 714-733.

Neifar L., Tyler G.A., Euzet L. 2001: Two new species of Macrobothridium (Cestoda: Diphyllidea) from rhinobatid elasmobranchs in the Gulf of Gabes, Tunisia, with notes on the status of the genus. J. Parasitol. 87: 673-680.

Nishiyama T., Takahashi Y., Ishizaka S., Araki T. 1993: Scanning electron microscopic observation of the scolex of Diplogonoporus grandis. J. Nara Med. Assoc. 31: 262-264.

NovaK M., DowsetT J.A. 1983: Scanning electron microscopy of the metacestode of Taenia crassiceps. Int. J. Parasitol. 13: 383-388

Olson P.D., CaIra J.N. 2001: Two new species of Litobothrium Dailey, 1969 (Cestoda: Litobothriidea) from thresher sharks in the Gulf of California, Mexico, with redescriptions of two species in the genus. Syst. Parasitol. 48: 159-177.

PALM H.W. 1995: Untersuchungen zur Systematik von Rüsselbandwürmern (Cestoda: Trypanorhyncha) aus atlantischen Fischen. Berichte aus dem Institut für Meereskunde an der Christian-A1brechts-Universität Kiel, No. 275, 238 pp.

Palm H.W. 1997: Trypanorhynch cestodes of commercial fishes from northeast Brazilian coastal waters. Mem. Inst. Oswaldo Cruz 92: 69-79.

PALm H.W. 2000: Trypanorhynch cestodes from Indonesian coastal waters (East Indian Ocean). Folia Parasitol. 47: 123-134.

PaLm H.W. 2004: The Trypanorhyncha Diesing, 1863. PKSPL-IPB Press, Bogor, 710 pp.

PALm H.W. 2008: Surface ultrastructure of the elasmobranchia parasitizing Grillotiella exilis and Pseudonybelinia odontacantha (Trypanorhyncha, Cestoda). Zoomorphology 127: 249-258.
Palm H.W., Mundt U., Overstreet R. 2000: Sensory receptors and surface ultrastructure of trypanorhynch cestodes. Parasitol. Res. 86: 821-833.

Palm H.W., Poynton S.L., Rutledge P. 1998: Surface ultrastructure of plerocercoids of Bombycirhynchus sphyraenaicum (Pintner, 1930) (Cestoda: Trypanorhyncha). Parasitol. Res. 84: 195-204.

Palm H.W., Schröder P. 2001: Cestode parasites from the elasmobranchs Heptranchias perlo and Deania from the Great Meteor Bank, central East Atlantic. Aquat. Living Resour. 14: 137-144.

Park W.-C., Kang S.-Y., LeE S.-H. 1981: Study on the fine structure of sparganum tegument. Chung-Ang J. Med. 6: 29-38.

Poddubnaya L.G. 1995: Peculiarities of the integument genesis in procercoids of caryophyllidean cestodes. Parazitologiya 29: 13-18. (In Russian, with English summary.)

Poddubnaya L.G. 1996: A development of microtriches in caryophylloid cestodes. Parazitologiya 30: 126-131. (In Russian, with English summary.)

Poddubnaya L.G. 2002a: Ultrastructure of genital system ducts of Diphyllobothrium latum (Cestoda: Pseudophyllidea): the ducts of the female reproductive system. Parazitologiya 36: 79-87. (In Russian, with English summary.)

Poddubnaya L.G. 2002b: Ultrastructure of reproductive ducts in Diphyllobothrium latum (Cestoda, Pseudophyllidea) males. Zool. Zh. 81: 394-405. (In Russian, with English summary.)

Poddubnaya L.G. 2003a: Structure of reproductive systems of the amphicotyllide cestode Eubothrium rugosum (Cestoda, Pseudophyllidae). J. Evol. Biochem. Physiol. 39: 345-355.

Poddubnaya L.G. 2003b: Ultrastructure of reproductive organs and ducts in the progenetic species Archigetes sieboldi (Cestoda, Caryophyllidea). Zool. Zh. 82: 1038-1050. (In Russian, with English summary.)

Poddubnaya L.G. 2007: Fine structure of the cirrus sac and vagina of progenetic Diplocotyle olrikii (Cestoda: Spathebothriidea). Parazitologiya 41: 299-308. (In Russian, with English summary.)

Poddubnaya L., Bruñanská M., Kuchta R., Scholz T. 2006: First evidence of the presence of microtriches in the Gyrocotylidea. J. Parasitol. 92: 703-707.

Poddubnaya L.G., Davydov V.G., Kuperman B.I. 1986: [Morphofunctional study of some cestodes of the order Caryophyllidea (Cestoda).] Trud. Inst. Biol. Vnutr. Vod 53: 208-217. (In Russian.)

Poddubnaya L.G., Mackiewicz J.S. 2009: Ultrastructure of the cirrus sac of echinophallid tapeworms (Cestoda, Bothriocephalidea) and the terminology of cirrus hard structures. Int. J. Parasitol. 39: 381-390.

Poddubnaya L.G., Mackiewicz J.S., Bruňanská M., Dezfuli B.S. 2005a: Fine structure of the male reproductive ducts, vagina and seminal receptacle of Cyathocephalus truncatus (Cestoda: Spathebothriidea). Folia Parasitol. 52: 241-250.

Poddubnaya L.G., Mackiewicz J.S., Bruňanská M., Scholz T. 2005b: Fine structure of the female reproductive ducts of Cyathocephalus truncatus (Cestoda: Spathebothriidea), from salmonid fish. Folia Parasitol. 52: 323-338.

Poddubnaya L.G., Mackiewicz J.S., Kuperman B.I. 2003: Ultrastructure of Archigetes sieboldi (Cestoda: Caryophyllidea): relationship between progenesis, development and evolution. Folia Parasitol. 50: 275-292.

Poddubnaya L.G., Scholz T., Kuchta R., Levron C., Bruñanská M. 2007: Ultrastructure of the proglottid tegument (neodermis) of the cestode Echinophallus wageneri (Pseudophyllidea: Echi- 
nophallidae), a parasite of the bathypelagic fish Centrolophus niger. Parasitol. Res. 101: 373-383.

Pool W., Chubв J.C. 1985: A critical scanning electron microscope study of the scolex of Bothriocephalus acheilognathi Yamaguti, 1934, with a review of the taxonomic history of the genus Bothriocephalus parasitizing cyprinid fishes. Syst. Parasitol. 7: 199-211.

Pratt H.S. 1909: The cuticula and subcuticula of trematodes and cestodes. Am. Natur. 43: 705-729.

Probert A.J., Stobart B. 1989: Echinobothrium clavatum n. sp. (Cestoda, Diphyllidea) from the spiral valve of Raja clavata L., 1758 , including a note on its ultrastructure and a key to species of the genus. Syst. Parasitol. 13: 71-79.

Race G.J., Larsh J.E., Jr., Esch G.W., Martin J.H. 1965: A study of the larval stage of Multiceps serialis by electron microscopy. J. Parasitol. 51: 364-369.

READ C.P. 1955: Intestinal physiology and the host-parasite relationship. In: W.H. Cole (Ed.), Some Physiological Aspects and Consequences of Parasitism. Rutgers University Press, New Brunswick, New Jersey, pp. 27-49.

ReEs G. 1958: A comparison of the structure of the scolex of Bothriocephalus scorpii (Müller 1776) and Clestobothrium crassiceps (Rud. 1819) and the mode of attachment of the scolex to the intestine of the host. Parasitology 48: 468-492.

Rees G. 1973: The ultrastructure of the cysticercoid of Tatria octacantha Rees, 1973 (Cyclophyllidea: Amabiliidae) from the haemocoele of the damsel-fly nymphs Pyrrhosoma nymphula, Sulz and Enallagma cyathigerum, Charp. Parasitology 67: 83103.

ReGo A.A. 1999: Scolex morphology of proteocephalid cestodes parasites of neotropical freshwater fishes. Mem. Inst. Oswaldo Cruz 94: 37-52.

Rego A.A., Chubb J.C., Pavanelli G.C. 1999: Cestodes in South American freshwater teleost fishes: keys of genera and brief description of species. Rev. Brasil. Zool. 16: 299-367.

REYDA F.B. 2008: Intestinal helminths of freshwater stingrays in southeastern Peru, and a new genus and two new species of cestode. J. Parasitol. 94: 684-699.

Reyda F.B., Caira J.N. 2006: Five new species of Acanthobothrium (Cestoda: Tetraphyllidea) from Himantura uarnacoides (Myliobatiformes: Dasyatidae) in Malaysian Borneo. Comp. Parasitol. 73: 49-71.

Richards K.S., Arme C. 1981a: Observations on the microtriches and stages in their development and emergence in Caryophyllaeus laticeps (Caryophyllidea: Cestoda). Int. J. Parasitol. 11: 369-375.

Richards K.S., Arme C. 1981b: The ultrastructure of the scolexneck syncytium, neck cells and frontal gland cells of Caryophyllaeus laticeps (Caryophyllidea: Cestoda). Parasitology 83: 477-487.

Richards K.S., Arme C. 1984: Maturation of the scolex syncytium in the metacestode of Hymenolepis diminuta, with special reference to microthrix formation. Parasitology 88: 341-349.

Richmond C., CAira J.N. 1991: Morphological investigations into Floriceps minacanthus (Trypanorhyncha: Lacistorhynchidae) with analysis of the systematic utility of scolex microtriches. Syst. Parasitol. 19: 25-32.

Rietschel P.E. 1935: Zur Bewegungsphysiologie der Cestoden. Zool. Anz. 111: 109-111.

Rifkin E., Cheng T.C., Hohl H.R. 1970: The fine structure of the tegument of Tylocephalum metacestodes: with emphasis on a new type of microvilli. J. Morphol. 130: 11-24.
Rogan M.T., Richards K.S. 1987: Echinococcus granulosus: changes in the surface ultrastructure during protoscolex formation. Parasitology 94: 359-367.

RoHDE K. 1986: Ultrastructural studies of Austramphilina elongata Johnston, 1931 (Cestoda, Amphilinidea). Zoomorphology 106: 91-102.

Rohde K., Georgi M. 1983: Structure and development of Austramphilina elongata Johnston, 1931 (Cestodaria: Amphilinidea). Int. J. Parasitol. 13: 273-287.

Rosario B. 1962: The ultrastructure of the cuticle in the cestodes $H$. nana and H. diminuta. The Fifth International Congress for Electron Microscopy, Philadelphia, Pennsylvania, August 29th to September 5th, 1962 2: LL-12.

Rothman A.H. 1959: The physiology of tapeworms, correlated to structures seen with the electron microscope. J. Parasitol. 45 (Suppl.): 28.

Rothman A.H. 1963: Electron microscopic studies of tapeworms: the surface structures of Hymenolepis diminuta (Rudolphi, 1819) Blanchard, 1891. Trans. Am. Microsc. Soc. 82: 22-30.

RuHnKe T.R. 1993: A new species of Clistobothrium (Cestoda: Tetraphyllidea), with an evaluation of the systematic status of the genus. J. Parasitol. 79: 37-43.

RuhnKe T.R. 1994a: Paraorygmatobothrium barberi n. g., n. sp. (Cestoda: Tetraphyllidea), with amended descriptions of two species transferred to the genus. Syst. Parasitol. 28: 65-79.

RuHnKe T.R. 1994b: Resurrection of Anthocephalum Linton, 1890 (Cestoda: Tetraphyllidea) and taxonomic information on five proposed members. Syst. Parasitol. 29: 159-176.

RuhnKe T.R. 1996a: Taxonomic resolution of Phyllobothrium van Beneden (Cestoda: Tetraphyllidea) and a description of a new species from the leopard shark Triakis semifasciata. Syst. Parasitol. 33: 1-12.

RUHNKE T.R. 1996b: Systematic resolution of Crossobothrium Linton, 1889, and taxonomic resolution of four species allocated to that genus. J. Parasitol. 82: 793-800.

RuhnKe T.R., CAIRA J.N. 2009: Two new species of Anthobothrium van Beneden, 1850 (Tetraphyllidea: Phyllobothriidae) from carcharhinid sharks, with a redescription of Anthobothrium laciniatum. Syst. Parasitol. 72: 217-227.

RuhnKe T.R., Caira J.N., Carpenter S.D. 2006a: Orectolobicestus n. g. (Cestoda: Tetraphyllidea), with the description of five new species and the transfer of Phyllobothrium chiloscyllii to the new genus. Syst. Parasitol. 65: 215-233.

Ruhnke T.R., Carpenter S.D. 2008: Two new species of Paraorygmatobothrium Ruhnke, 1994 (Tetraphyllidea: Phyllobothriidae) from the smooth-hound Mustelus mustelus (L.) and the gummy shark $M$. antarcticus Günther (Carcharhiniformes: Triakidae). Syst Parasitol. 71: 213-222.

Ruhnke T.R., Healy C.J., Shapero S. 2006b: Two new species of Paraorygmatobothrium (Cestoda: Tetraphyllidea) from weasel sharks (Carcharhiniformes: Hemigaleidae) of Australia and Borneo. J. Parasitol. 92: 145-150.

Ruhnke T.R., Thompson V.A. 2006: Two new species of Paraorygmatobothrium (Tetraphyllidea: Phyllobothriidae) from the lemon sharks Negaprion brevirostris and Negaprion acutidens (Carcharhiniformes: Carcharhinidae). Comp. Parasitol. 73: 35-47.

RundeLL H.L. 1957: Electron microscope studies of the body covering of cestodes. PhD Thesis, State University of Iowa, $48 \mathrm{pp}$.

Schiefferdecker P. 1874: Beiträge zur Kenntnis des feineren Baues der Taenien. Jena. Z. Naturwiss. 8: 458-487.

Scholz T., de Chambrier A., Kuchta R. 2008: Redescription of the tapeworm Monticellia amazonica de Chambrier et Vaucher, 
1997 (Cestoda, Proteocephalidea), a parasite of Calophysus macropterus (Siluriformes, Pimelodidae) from the Amazon River. Acta Parasitol. 53: 30-35.

Scholz T., ŽďÁrská Z., de Chambrier A., Drábek R. 1999: Scolex morphology of the cestode Silurotaenia siluri (Batsch, 1786) (Proteocephalidae: Gangesiinae), a parasite of European wels (Silurus glanis). Parasitol. Res. 85: 1-6.

Schramlová J., Lavrov I.L. 1981: Scanning electron microscopic studies on the scolex surface of Hydatigera krepkogorski (Schulz et Landa, 1934) larva. Folia Parasitol. 28: 191-192.

SEIF A.I. 1992: Ultrastructural study of the tegument of Cotugnia polyacantha and Killigrewia streptopelia inhabiting the dove Streptopelia senegalensis aegyptiaca. J. Egypt. Soc. Parasitol. 22: $817-826$.

Shields J.D. 1985: Surface morphology and description of Otobothrium kurisi new species (Cestoda: Trypanorhyncha) from a hammerhead shark, Sphyrna lewini. Int. J. Parasitol. 15: 635643.

SidDiQui E.H. 1963: The cuticle of cysticerci of Taenia saginata, T. hydatigena, and T. pisiformis. Q. J. Microsc. Sci. 104: 141-144.

Sмүтн J.D. 1969: Physiology of Cestodes. Oliver \& Boyd, Edinburgh, $279 \mathrm{pp}$.

Smyth J.D., McManus D.P. 1989: The Physiology and Biochemistry of Cestodes. Cambridge University Press, New York, 398 pp.

Sommer F.B.G., Landois L. 1872: Ueber den Bau der geschlechtsreifen Glieder von Bothriocephalus latus Bremser (Beiträge zur Anatomie der Cestoden). Z. Wiss. Zool. 22: 40-99.

STEUdener F. 1877: Untersuchungen über den feineren Bau der Cestoden. Abh. Naturforsch. Ges. Halle 13: 277-316.

Stoitsova S.R., Georgiev B.B., Vasileva G.P., Jordanova M. 2001: Rostellar apparatus of Fernandezia spinosissima (von Linstow, 1894) (Cestoda, Cyclophyllidea, Davaineidae): microanatomy and fine structure. Acta Zool. 82: 241-250.

Tedesco J.L., Coggins J.R. 1980: Electron microscopy of the tumulus and origin of associated structures within the tegument of Eubothrium salvelini Schrank, 1790 (Cestoidea: Pseudophyllidea). Int. J. Parasitol. 10: 275-280.

Tномаs L.P. 1983: Fine structure of the tentacles and associated microanatomy of Haplobothrium globuliforme (Cestoda: Pseudophyllidea). J. Parasitol. 69: 719-730.

Thompson R.C.A., Hayton A.R., Jue Sue L.P. 1980: An ultrastructural study of the microtriches of adult Proteocephalus tidswelli (Cestoda: Proteocephalidea). Z. Parasitenkd. 64: 95-111.

Thompson R.C.A., Houghton A., Zaman V. 1982: A study of the microtriches of adult Echinococcus granulosus by scanning electron microscopy. Int. J. Parasitol. 12: 579-583.

Threadgold L.T. 1962: An electron microscope study of the tegument and associated structures of Dipylidium caninum. Q. J. Microsc. Sci. 103: 135-140

Threadgold L.T. 1964: The ultrastructure of the tegument of Proteocephalus pollanicoli [sic]. Third European Regional Conference on Electron Microscopy, Prague, pp. 563-564.

THREADGOLD L.T. 1965: An electron microscope study of the tegument and associated structures of Proteocephalus pollanicoli. Parasitology 55: 467-472.

Threadgold L.T. 1984: Parasitic Platyhelminths. In: J. BereiterHahn, A.G. Matoltsy and K.S. Richards (Eds.), Biology of the Integument: I. Invertebrates (Vol. 1). Springer-Verlag, Berlin and New York, pp. 132-191.

Threadgold L.T., Dunn J. 1983: Taenia crassiceps: regional variations in ultrastructure and evidence of endocytosis in the cysticercus tegument. Exp. Parasitol. 55: 121-131.
Timofeev V.A., Kuperman B.I. 1972: [Appearance and formation of microtrichia in cestodes as exemplified by Triaenophorus nodulosus according to electron-microscope data.] Dokl. Akad. Nauk SSSR 207: 757-759. (In Russian.)

Tsuboi T., Torir M., Hirai K. 1993: Light and scanning electron microscopy of Diphyllobothrium pacificum expelled from man. Jpn. J. Parasitol. 42: 422-428.

Twohig M.E., Caira J.N., Fyler C.A. 2008: Two new cestode species from the dwarf whipray, Himantura walga (Batoidea: Dasyatidae), from Borneo, with comments on site and mode of attachment. J. Parasitol. 94: 1118-1127.

Tyler G.A. 2001: Diphyllidean cestodes of the Gulf of California, Mexico with descriptions of two new species of Echinobothrium (Cestoda: Diphyllidea). J. Parasitol. 87: 173-184.

Tyler G.A. 2006: A Monograph on the Diphyllidea (Platyhelminthes, Cestoda). Tapeworms of Elasmobranchs. Part II. University of Nebraska State Museum, Lincoln, Nebraska, 142 pp.

Tyler G.A., Caira J.N. 1999: Two new species of Echinobothrium (Cestoidea: Diphyllidea) from myliobatiform elasmobranchs in the Gulf of California, México. J. Parasitol. 85: 327-335.

UBELAKER J.E. 1980: Structure and ultrastructure of the larvae and metacestodes of Hymenolepis diminuta. In: H.P. Arai (Ed.), Biology of the Tapeworm Hymenolepis diminuta. Academic Press, New York, pp. 59-156.

Ubelaker J.E., Allison V.F., Specian R.D. 1973: Surface topography of Hymenolepis diminuta by scanning electron microscopy. J. Parasitol. 59: 667-671.

Valkounová J., Prokopič J. 1980: Morphology of the cysticercoid of Hymenolepis erinacei (Gmelin, 1789). Folia Parasitol. 27: $53-57$.

Voge M. 1962: Observations on the structure of the cysticercus of Taenia hydatigena Pallas, 1766. Proc. Helminthol. Soc. Wash. 29: 62-66.

Voge M. 1963: Observations on the structure of cysticerci of Taenia solium and T. saginata (Cestoda: Taeniidae). J. Parasitol. 49: 85-90.

Voge M., Sogandares-Bernal F., Martin J.H. 1979: Fine structure of the tegument of Mesocestoides tetrathyridia by scanning and transmission electron microscopy. J. Parasitol. 65: 562-567.

W Aitz J.A. 1961: Studies of the ultrastructure of larval Hydatigera taeniaeformis. J. Parasitol. 47 (Suppl.): 27.

Whittaker F.H., Apkarian R.P., Curless B., Carvajal J.G. 1985: Scanning electron microscopy of the scolices of the cestodes Parachristianella monomegacantha Kruse 1959 (Trypanorhyncha) and Phyllobothrium sp. Beneden 1849 (Tetraphyllidea). J. Parasitol. 71: 376-381.

Whittaker F.H., Carvajal J.G. 1980: Scanning electron microscopy of scolices of some cestodes from elasmobranchs. Proc. Helminthol. Soc. Wash. 47: 256-259.

Whittaker F.H., Carvajal J.G., Apkarian R. 1982: Scanning electron microscopy of the scolex of Grillotia dollfusi Carvajal 1971 (Cestoda: Trypanorhyncha). J. Parasitol. 68: 1173-1175.

Yamane Y. 1968: On the fine structure of Diphyllobothrium erina$c e i$ with special reference to the tegument. Yonago Acta Med. 12: 169-181.

Yamane Y., Bylund G., Abe K., Osaki Y., Окamoto T. 1989: Scanning electron microscopic study of four Diphyllobothrium species. Parasitol. Res. 75: 238-244.

Yamane Y., Maejima J., Yazaki S. 1975: Scanning electron microscopic observation of the tegumental structure of diphyllobothriid cestodes. Yonago Acta Med. 19: 197-206. 
Yamane Y., Nakagawa A., Makino Y., Hirai K. 1982a: An electron microscopic study of subtegumental cells and associated structures of Spirometra erinacei. Jpn. J. Parasitol. 31: 487-497.

Yamane Y., Nakagawa A., Makino Y., Yazaki S., Fukumoto S. 1982b: Ultrastructure of the tegument of Diphyllobothrium latum by scanning electron microscopy. Jpn. J. Parasitol. 31: 33-46.

Yazaki S., Fukumoto S., Maejima J. 1990: Cytoskeletal construction and alteration of microtriches of Diphyllobothrium hottai, during early development stages. Jpn. J. Parasitol. 39: 165-171.

Young R.T. 1908: The histogenesis of Cysticercus pisiformis. Zool. Jahrb. 26: 183-254.

ŽĎÁRsKÁ Z., NEBEsÁŘovÁ J. 1997: Ultrastructure of three types of scolex gland cells in adult Bothriocephalus claviceps (Cestoda: Pseudophyllidea). Folia Parasitol. 44: 139-146.
ŽĎÁRsKÁ Z., NebesÁR̆ovÁ J. 1999: Regional ultrastructural differences of the scolex and neck tegument of Proteocephalus macrocephalus (Eucestoda: Proteocephalidae). Folia Parasitol. 46: 279-283.

Ž̀̃ÁRSKÁ Z., NebAsÁŘová J. 2003: Ultrastructure of the early rostellum of Silurotaenia siluri (Batsch, 1786) (Cestoda: Proteocephalidae). Parasitol. Res. 89: 495-500.

ŽĎÁRSKÁ Z., NebesÁŘ́ová J. 2005: Transmission electron microscopy of the scolex and neck microtriches of Silurotaenia siluri (Batsch, 1786) (Cestoda: Proteocephalidea). Parasitol. Res. 97: $98-102$.

Ž̃̌́́rská Z., Scholz T., NebesáŘová J. 2004: Ultrastructure of the apical glandular region of the scolex of Proteocephalus torulosus (Cestoda: Proteocephalidae). Folia Parasitol. 51: 333-338. 